UNIVERSIDADE DE BRASÍLIA

FACULDADE DE ECONOMIA, ADMINISTRAÇÃO, CONTABILIDADE E CIÊNCIA DA INFORMAÇÃO E DOCUMENTAÇÃO - FACE

PROGRAMA DE PÓS-GRADUAÇÃO EM ADMINISTRAÇÃO - PPGA

KELEN CRISTINA RODRIGUES ROSA

EVOLUÇÃO HISTÓRICA DOS ACORDOS COLETIVOS DE TRABALHO E OS RESULTADOS DOS INDICADORES DE DESEMPENHO DE GESTÃO ORGANIZACIONAL NOS CORREIOS

Brasília - DF

Setembro, 2009 
KELEN CRISTINA RODRIGUES ROSA

\title{
EVOLUÇÃO HISTÓRICA DOS ACORDOS COLETIVOS DE TRABALHO E OS RESULTADOS DOS INDICADORES DE DESEMPENHO DE GESTÃO ORGANIZACIONAL NOS CORREIOS
}

Projeto de monografia apresentado no curso de Gestão de Pessoas do Programa de Pós-Graduação em Administração da Faculdade de Economia, Administração, Contabilidade e Ciência da Informação e Documentação - FACE, Universidade de Brasília, como requisito parcial para obtenção do grau de especialista em Gestão de Pessoas.

Orientador: Prof. Dr. Eleuní Antonio de Andrade Melo.

\author{
Brasília - DF
}

Setembro, 2009 


\section{RESUMO}

O sucesso de um acordo coletivo de trabalho depende tanto das condições específicas da negociação em si, quanto das possibilidades oferecidas pelo contexto econômico, político e social em que a negociação acontece e também dos objetivos e metas definidos pelas partes em um determinado tempo. Esse trabalho tem como objetivo analisar a evolução dos acordos coletivos da Empresa Brasileira de Correios e Telégrafos (ECT), dos períodos de 2002, 2004, 2006 e 2008, e a influência desses acordos no resultado dos indicadores de gestão organizacional: clima organizacional e desempenho operacional. Com vistas a realizar a investigação proposta, buscouse auxílio no método de pesquisa do estudo de caso. Ao longo deste trabalho houve as explicações das fases da negociação coletiva e as ações adotadas pela empresa. A partir daí procurou-se analisar os resultados dos indicadores. Os resultados obtidos permitiram a observação da evolução nas tratativas do processo de negociação e foi possível concluir que ambos os indicadores - clima organizacional e desempenho operacional - são influenciados pelas negociações.

Palavras-chave: Acordo Coletivo - Negociação Coletiva - Clima Organizacional - Desempenho Operacional. 


\section{SUMARIO}

1. INTRODUÇÃO

2. REFERENCIAL TEÓRICO

2.1. O Processo de negociação coletiva segundo a OIT 9

2.2. Evolução histórica da negociação coletiva de trabalho no Brasil 10

2.3. Negociação em Ação 12

2.3.1. Aplicações no Campo Organizacional 12

2.3.1.1 A negociação para Lewicki e Hiam 12

2.3.1.2. A negociação para Fisher, Ury e Patton 17

2.4. Indicadores de Gestão Organizacional 24

2.4.1. Clima Organizacional 24

2.4.1.1. Aplicações no Campo Organizacional 24

2.4.2. Indicadores de Desempenho 25

2.4.2.1. Aplicações no Campo Organizacional26

3. METODOLOGIA

3.1. Tipo de Pesquisa

3.2. Unidade de análise 27

3.3. Instrumento de Coleta de Dados 28

3.4. Procedimentos de Coleta de Dados 28

3.5. Análise de Dados 29

4. RESULTADOS

4.1. O Processo de Negociação Coletiva na ECT

4.2. Clima Organizacional

4.3. Qualidade Operacional

5. DISCUSSÃO DOS RESULTADOS

6. CONCLUSÃO 
APÊNDICE A

APÊNDICE B 52

APÊNDICE C 55

\section{LISTA DE QUADROS}

Quadro 1 Interações Possíveis entre Negociadores de Estilos Diferentes ------------------------- 17

Quadro 2 Indicadores sobre as quatro perspectivas do Balanced Scorecard ----------------------- 26

Quadro 3 Quantidades de CEE avaliados neste estudo, classificadas por grupo e DR ---------- 30

Quadro 4 Ações empreendidas pela organização pré, durante e pós-greve ----------------------- 34

Quadro 5 Etapas da negociação, comparativo entre a teoria e a aplicação pela ECT ----------- 35

Quadro 6 As 5 macro-etapas do ciclo de gestão do clima organizacional da ECT --------------- 37

Quadro 7 Fatores e conceitos da pesquisa de clima organizacional da ECT --------------------- 39

\section{LISTA DE FIGURAS}

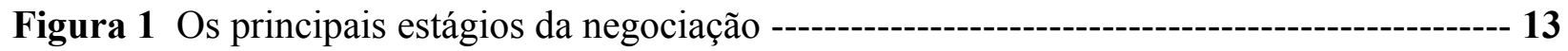

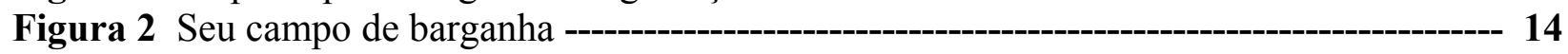

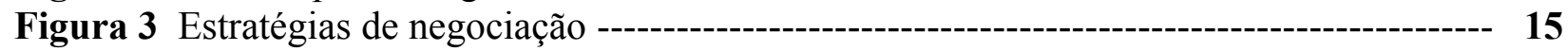

\section{LISTA DE GRÁFICOS}

Gráfico 1 Série histórica dos ciclos das pesquisas de clima ------------------------------------- 38 Gráfico 2 Evolução das quantidades de CEE do grupo 1, de 37 unidades, com resultados da

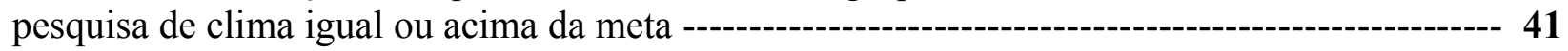

Gráfico 3 Evolução das quantidades de CEE do grupo 2, de 18 unidades, com resultados da

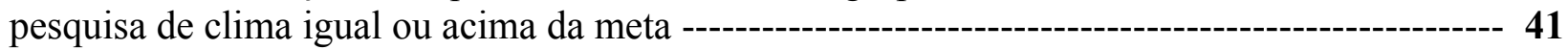

Gráfico 4 Evolução das quantidades de CEE do grupo 3, de 9 unidades, com resultados da pesquisa de clima igual ou acima da meta -------------------------------------------------------- 41

Gráfico 5 Evolução das quantidades de CEE do grupo 4, de 4 unidades, com resultados da

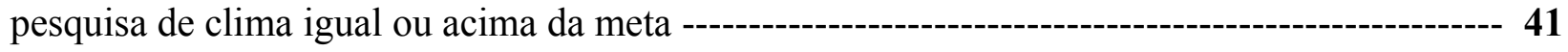

Gráfico 6 Evolução das quantidades de CEE do grupo 5, de 2 unidades, com resultados da

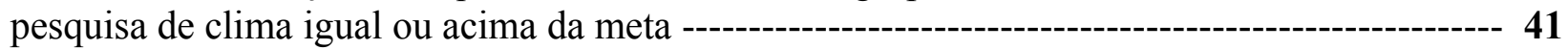

\section{LISTA DE TABELAS}

Tabela 1 Critério de Interpretação e Análise dos resultados das Pesquisas de Clima Organizacional

Tabela 2 Quantidade e percentual de CEE que obtiveram resultado do IDO do serviço SEDEX 


\section{INTRODUÇÃ̃O}

O presente trabalho propõe-se a analisar a evolução dos acordos coletivos, verificando a ocorrência de alterações entre as cláusulas, dos períodos de 2002, 2004, 2006 e 2008 da Empresa Brasileira de Correios e Telégrafos (ECT), avaliando a influência desses acordos no resultado dos indicadores de gestão organizacional. Serão considerados os seguintes indicadores organizacionais: clima organizacional e desempenho operacional.

O sucesso de um acordo coletivo de trabalho depende tanto das condições específicas da negociação em si, quanto das possibilidades oferecidas pelo contexto econômico, político e social em que a negociação acontece e também dos objetivos e metas definidos pelas partes em um determinado tempo.

A negociação, assim como os conflitos são inerentes à vida, pois acompanham o ser humano desde o nascimento. Não apenas os conflitos é que são negociados, mas também acordos, parcerias e contratos (CAVALCANTI, 2003).

A Constituição Federal de 1988, no art. $7^{\circ}$ prevê dentre os direitos dos trabalhadores "a realização das convenções e acordos coletivos de trabalho" (BRASIL, 2005). Em grande parte o resultado dos acordos coletivos celebrados é conseqüência da maneira como são gerenciadas as relações de trabalho na organização. Dessa forma, pode-se considerar que as relações de trabalho são essencialmente móveis e cambiáveis, necessitando de permanentes ajustes. Para tanto, nada mais adequado do que o processo de negociação coletiva, pelo qual os legítimos representantes de empregados e empregadores estabelecem as bases e as condições das convenções e acordos coletivos de trabalho, que deverão balizar as relações individuais e coletivas na esfera de cada categoria (GERNIGON, et al., 2002).

Os acordos coletivos de trabalho foram regulamentados pela Consolidação das Leis do Trabalho (CLT), outorgada em 1943, em plena ditadura do Estado Novo, pelo presidente Getúlio Vargas. Até então, as relações de trabalho eram pautadas pelo que se poderia chamar "liberalismo clássico", portanto, eram assentadas numa lógica individualista que recusava a ação coletiva dos trabalhadores (WENDLAND, 2006). Segundo a CLT o acordo coletivo é definido como o contrato de caráter normativo entre entidades sindicais com uma ou mais empresas, que estipula salários e condições de trabalho aplicáveis no âmbito da empresa ou das empresas acordantes às 
respectivas relações de trabalho. $\mathrm{O}$ acordo coletivo exige um processo prévio de negociação entre as partes: é a chamada negociação coletiva.

O Decreto $\mathrm{n}^{\mathrm{o}} .908$, de 31 de agosto de 1993, fixa diretrizes para as negociações coletivas de trabalho de que participam as entidades estatais. O parágrafo único do art. $2^{\circ}$ estabelece que: "todas as cláusulas do acordo coletivo vigente deverão ser objeto de negociação a cada nova database" e o art. $4^{\circ}$ prevê que: "o acordo coletivo vigorará por prazo não superior a 12 (doze) meses" (BRASIL, 1993).

As negociações entre administração e trabalhadores dependem muito de uma boa preparação. O típico contrato coletivo com o sindicato é complexo demais para ser deixado para o último minuto. Hoje em dia é comum, e até mesmo necessário, preparar-se para as negociações durante pelo menos seis meses ou um ano antes que elas comecem.

Tendo em vista a relevância das negociações coletivas do trabalho para a vida organizacional, acredita-se que o seu resultado também provoque impacto no desempenho da organização como um todo. Assim, o presente trabalho será delineado pelos objetivos apresentados a seguir:

O objetivo geral consiste em identificar a influência dos acordos coletivos de trabalho nos resultados dos indicadores de gestão organizacional: clima organizacional e desempenho operacional nos Correios. De maneira específica os objetivos são:

a) Contextualizar a evolução dos acordos coletivos de trabalho nos Correios;

b) Avaliar a relação das negociações nos resultados dos indicadores de gestão organizacional: clima organizacional e os indicadores de desempenho operacional e

c) Verificar a evolução das políticas dos acordos coletivos sobre as relações de trabalho.

O tema negociação vem passando por desenvolvimento intenso nos últimos anos, tanto no campo acadêmico como no profissional. No entanto, a produção científica sobre o assunto no Brasil, especialmente, no que diz respeito à negociação coletiva na administração pública é pequena.

Dos artigos publicados observa-se mais um enfoque teórico do que prático, tais como: negociação coletiva: tratamento teórico e prático de Melo (1991), que apresenta uma abordagem teórica do processo de negociação coletiva e relato de pesquisa realizada em Minas Gerais, cujos resultados estimulam uma reflexão sobre a necessidade de profissionais da área de Recursos 
Humanos desenvolverem modelos e propostas, tomando como referência de ação o contexto das relações de trabalho.

A negociação faz parte da vida. Na economia moderna, cada organização insere-se em intrincadas redes relacionais. Por meio da negociação, elas sobrevivem, construindo e preservando relacionamentos internos e externos. Negociar reflete, justamente, a habilidade de superar conflitos e conciliar interesses, cuidando não só do lado quantitativo (preços, condições), mas também do qualitativo (respeito aos indivíduos, relacionamentos de longo prazo).

A negociação surge da necessidade de conciliar os conflitos de interesses com o objetivo de chegar a resultados mutuamente satisfatórios.

Num sentido mais amplo, negociação é o processo de buscar aceitação de idéias, propósitos ou interesses visando o melhor resultado possível, de tal modo que as partes envolvidas terminem a negociação conscientes de que foram ouvidas, de que tivessem oportunidade de apresentar toda a sua argumentação e de que o produto final seja maior que a soma das contribuições individuais (JUNQUEIRA, 1998, p. 12).

Segundo Robbins (2005, p. 333) “o conflito desafia o status quo e, por isso, estimula a criação de novas idéias, promove a reavaliação das metas e das atividades do grupo e aumenta a probabilidade de que este responda às mudanças”.

Popadiuk et al. (2006) destaca que a análise de indicadores deve permitir conclusões relevantes e que levem à tomada de decisão nos diversos níveis da organização. Além disso, os indicadores ajudam a revelar tendências, permite projeções, estabelecimento de relações de causa e efeito e também permitem comparações com a concorrência e com referenciais de excelência. São instrumento de planejamento, gerenciamento e motivação, pois direcionam a empresa para os objetivos, organizam ações e conferem visibilidade aos resultados alcançados.

Este trabalho é constituído desta parte introdutória, onde é apresentado o tema, a contextualização do problema de pesquisa e os objetivos de sua realização. Em seguida é apresentado o referencial teórico acerca do processo de negociação coletiva, dos indicadores: clima organizacional e desempenho operacional, suas origens, conceitos e aplicações no campo organizacional. A terceira parte trata da metodologia utilizada para analisar e retratar os acordos coletivos e os indicadores de gestão organizacional. Por fim, são apresentados e discutidos os resultados encontrados e uma análise conclusiva. 


\section{REFERENCIAL TEÓRICO}

Este capítulo contém uma análise da produção científica sobre negociação e os indicadores organizacionais: clima organizacional e desempenho. Este bloco inicia-se com a descrição do processo de negociação coletiva segundo a Organização Internacional do Trabalho (OIT) e a evolução da negociação coletiva de trabalho no Brasil. Em seguida o leitor visualiza os conceitos e as abordagens organizacionais sobre a negociação e os indicadores.

\subsection{O Processo de negociação coletiva segundo a OIT}

De maneira geral o alcance da negociação no setor público é mais limitado que no setor privado. Nas duas realidades (pública e privada) o reconhecimento da negociação coletiva está limitado pelo fato de algumas questões serem reservadas para a adoção unilateral por parte da administração.

"A negociação coletiva é concebida nos instrumentos da OIT como uma atividade ou processo destinado à conclusão de um contrato ou acordo coletivo" (GERNIGON, et al., 2002, p. 22).

$\mathrm{O}$ “direito de sindicalização e negociação coletiva" é configurado pela Convenção n 98 (1949) da OIT. Este tratado internacional foi ratificado até 2009 por 182 Estados membros da OIT, e pelo Brasil em 1952, e faz parte da Declaração da OIT sobre os Princípios e Direitos Fundamentais no Trabalho e seu Seguimento (1998) da qual o Brasil é signatário.

A OIT foi criada pela Conferência de Paz após a Primeira Guerra Mundial. A sua Constituição converteu-se na Parte XIII do Tratado de Versalhes. Em 1944, à luz dos efeitos da Grande Depressão a da Segunda Guerra Mundial, a OIT adotou a Declaração da Filadélfia como anexo da sua Constituição.

Em 1944, a Declaração de Filadélfia reconheceu "a obrigação solene da OIT de fomentar, entre todas as nações do mundo, programas que permitam alcançar o reconhecimento efetivo do direito de negociação coletiva" e tomou nota que este princípio é plenamente aplicável a todos os povos.

Em 1949, a Conferência Internacional do Trabalho adotou a Convenção sobre o direito de sindicalização e direitos fundamentais no trabalho e seu seguimento. Em 1998 foi adotada 
Declaração da OIT sobre os Princípios e Direitos Fundamentais no Trabalho e seu Seguimento. É uma reafirmação universal do compromisso dos Estados Membros e da comunidade internacional em geral de respeitar, promover e aplicar um patamar mínimo de princípios e direitos no trabalho, que são reconhecidamente fundamentais para os trabalhadores.

Esses princípios e direitos fundamentais estão recolhidos em oito Convenções que cobrem quatro áreas básicas: liberdade sindical e direito à negociação coletiva, erradicação do trabalho infantil, eliminação do trabalho forçado e não discriminação no emprego ou ocupação.

O cumprimento pelos Estados membros da OIT dos princípios e direitos contidos nas convenções sobre a liberdade sindical e a negociação coletiva são examinados regularmente pelo Comitê de Liberdade Sindical da OIT. Esse comitê analisa queixas formais sobre a aplicação da Convenção 87 sobre a liberdade sindical e a proteção do direito à sindicalização e da Convenção 98 sobre o direito de sindicalização e de negociação coletiva.

A Convenção 87 sobre a liberdade sindical e proteção do direito de sindicalização (1948) estabelece o direito de todos os trabalhadores e empregados de constituir organizações que considerem convenientes e de a elas filiarem, sem prévia autorização, e dispõe sobre uma série de garantias para o livre funcionamento dessas organizações, em ingerência das autoridades públicas.

A Convenção 98 sobre o direito de sindicalização e de negociação coletiva (1949) estipula proteção contra todo ato de discriminação que reduza a liberdade sindical, proteção das organizações de trabalhadores e de empregadores contra atos de ingerência de umas nas outras, e medidas de promoção da negociação coletiva.

A seguir será apresentada a evolução conceitual da negociação coletiva de trabalho no Brasil que tem como fonte o trabalho Gernigon, et al. (2002).

\subsection{Evolução histórica da Negociação Coletiva de Trabalho no Brasil}

No Brasil, não existem procedimentos de negociação consolidados em lei. Como a dinâmica das relações são referidas nos "acertos informais" e em raras consultas, os movimentos de ajuste são próprios de cada realidade, sem qualquer característica geral.

A organização da prestação laboral ao Estado, com algum sentido técnico de modernidade, remonta à década de 30 do século XX, no governo do Presidente Getúlio Vargas. 
Imbuído do espírito reformista e percebendo a necessidade de modernizar o serviço público federal, de modo a garantir as suas políticas desenvolvimentistas e industriais, o Presidente Vargas empreendeu um gigantesco esforço na tentativa de organizar, sistematicamente, a estrutura administrativa federal brasileira.

Antes dele, sob o regime da República Velha, não existiam regras para o provimento dos cargos públicos, nem regime jurídico assim entendido, para então funcionários públicos. Prevalecia o regime patrimonialista em sua essência. A nomeação era um ato puramente político, do livre alvitre do chefe político, sem qualquer valoração de mérito ou necessidade da Administração.

Contra este estado de coisas, insurgiu-se o governo revolucionário de Vargas. Foi criado o Departamento Administrativo do Serviço Público (DASP), órgão público responsável pelas políticas de organização do serviço público. Como uma das primeiras medidas do DASP, destaca-se a regularização da situação dos funcionários públicos no Brasil, com a edição do primeiro Estatuto dos Funcionários Públicos Civis da União, datado de 1939.

Por outro lado, enquanto Getúlio Vargas cuidava, com o DASP, de mordenizar o serviço público, preocupava-se também em organizar o setor privado. Assim, com a criação do Ministério do Trabalho, iniciou uma vertiginosa sucessão de atos e fatos que culminaram com a edição, em 1943, da Consolidação das Leis do Trabalho (CLT).

O seu objetivo, com a legislação, era retirar o trabalhador brasileiro do mundo medieval no qual se encontrava, sem qualquer direito ou garantia. Para tanto, valeu-se da exitosa experiência italiana da "Carta Del Lavoro" e introduziu um regime contratual, de direito privado, bilateral, amparado em lei específica e fundamentado na hipossuficiência do trabalhador em matéria jurídica, o que resultou em legislação extremamente protecionista.

Este regime também denominado celetista tinha sua aplicação no mundo do direito privado, das empresas e negócios, não sendo cogitado apenas para o serviço público. Todavia, a partir da década de 70, também do século passado, o Governo Federal brasileiro, empolgado com a época do "milagre brasileiro", resolveu adotar o regime da CLT no serviço público, alegando que o regime estatutário era responsável pelo atraso da máquina estatal e que o êxito do regime trabalhista na iniciativa privada era demonstração suficiente de sua aplicabilidade também na seara pública. Naquele período, constatou-se, também, a larga criação de centenas de empresas estatais, submetidas à regulamentação da CLT. 
Assim, às vésperas da Constituição Federal (CF) de 1988, o quadro da prestação laboral do Estado brasileiro era o seguinte: o regime prevalecente adotado pela Constituição vigente (1967/1969) era o estatutário, mas ao seu lado conviviam formas anômalas de recrutamento, de caráter precatório e transitório e, em expressivo número, empregados celetistas da administração direta, autárquica e fundações públicas.

Com a Emenda Constitucional (EC) no 19/98, a eventual adoção do regime trabalhista pelas esferas do governo, trás como conseqüência um processo de negociação coletiva no âmbito do serviço público, ainda que com objeto reduzido em relação à negociação levada a cabo no mundo privado e mesmo nas empresas estatais, regidas pelo direito privado.

Em seguida serão apresentadas as aplicações organizacionais da negociação.

\subsection{Negociação em Ação}

Diversas definições de negociação podem ser encontradas na literatura, variando conforme os interesses, a formação e a especialização do respectivo autor. Neste tópico serão descritas duas visões a respeito do processo de negociação. Após, será examinada a relação entre elas e, da mesma forma, o processo de negociação coletiva nos Correios.

\subsubsection{Aplicações no Campo Organizacional}

Nos tópicos seguintes serão apresentadas as visões de Lewicki e Hiam (2003) e Fisher, Ury e Patton (1994) para o processo de negociação coletiva.

\subsubsection{A negociação para Lewicki e Hiam (2003)}

Segundo os autores uma forma de encarar a negociação é vê-la como um jogo. Em primeiro lugar, podemos entender o jogo. Não se trata de um processo totalmente aleatório. Em segundo lugar, no jogo existe uma sequência previsível de atividades. Os autores consideram que embora seja difícil prever exatamente como a outra parte agirá a qualquer hora, a sequência de uma negociação geralmente segue um padrão claro e fácil de entender. 
Em terceiro lugar, há os jogadores. Para os autores conhecer quem são os jogadores e o que fazem exerce uma influência muito grande em como se deve planejar e adotar as estratégias. Por fim, o jogo tem regras. Existem os "sim" e "não" nas negociações. E algumas negociações, as regras são claras, são colocadas por escrito e bastante explícitas. Em outras as regras são menos claras e não vêm por escrito.

Os autores consideram a negociação vendo-a em quatro estágios, conforme representado na Figura 1.

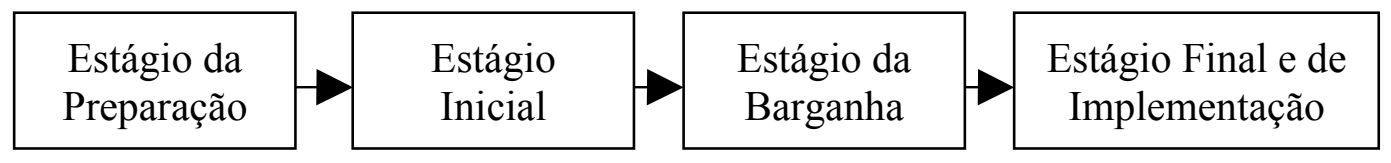

Figura 1 - Os principais estágios da negociação.

Fonte: Alexander Hiam e Roy Lewicki (2003).

\section{Estágio 1: Preparação}

O primeiro estágio da negociação é o da preparação. Este estágio compreende:

1. Coletar informações: O primeiro passo da negociação é o processo da coleta de informação. É necessário decidir que tipo de informação é preciso entre os dois tipos abaixo:

- Informações que ajudarão a definir os objetivos e argumentar para conseguir atingir os objetivos na negociação.

- Informações sobre a outra parte, suas metas e objetivos, como eles tendem a vê-lo, e o resultado que eles querem atingir na negociação.

2. Planejamento e definição de objetivos: Planejar e definir objetivos também são uma parte importante do estágio de preparação. Precisamos delinear a direção que queremos que a negociação tome, assim como é necessário despender um tempo para decidirmos o que pretendemos conseguir.

\section{Estágio 2: Início}

É no estágio inicial que se expõem os argumentos. É aí que entra a importância da clareza de objetivos, da argumentação eficaz para obter o que se quer, e da capacidade de ouvir atentamente a outra parte e o que ela pretende, para que se possa contra-argumentar, se for necessário. 


\section{Estágio 3: Barganhar}

Em uma negociação as partes normalmente sabem que as solicitações iniciais são exageradas e que uma das partes terá que fazer concessões para chegar a um acordo. Dentro da área de barganha incluem-se o ponto de partida, a meta, a resistência ou a desistência (Figura 2).

O ponto de partida é a sua primeira oferta à outra parte. Tal oferta pode depender do valor de mercado, do grau de sua necessidade em obter um resultado, do que espera que seja o ponto de partida da outra parte, das concessões que está disposto a fazer, ou do modo como se desenvolvem outras negociações no passado. Alguns desses fatores dependem do contexto da negociação.

A meta é o ponto de partida. E o ponto de desistência é valor alcançado que nos leva a desfazer o negócio.

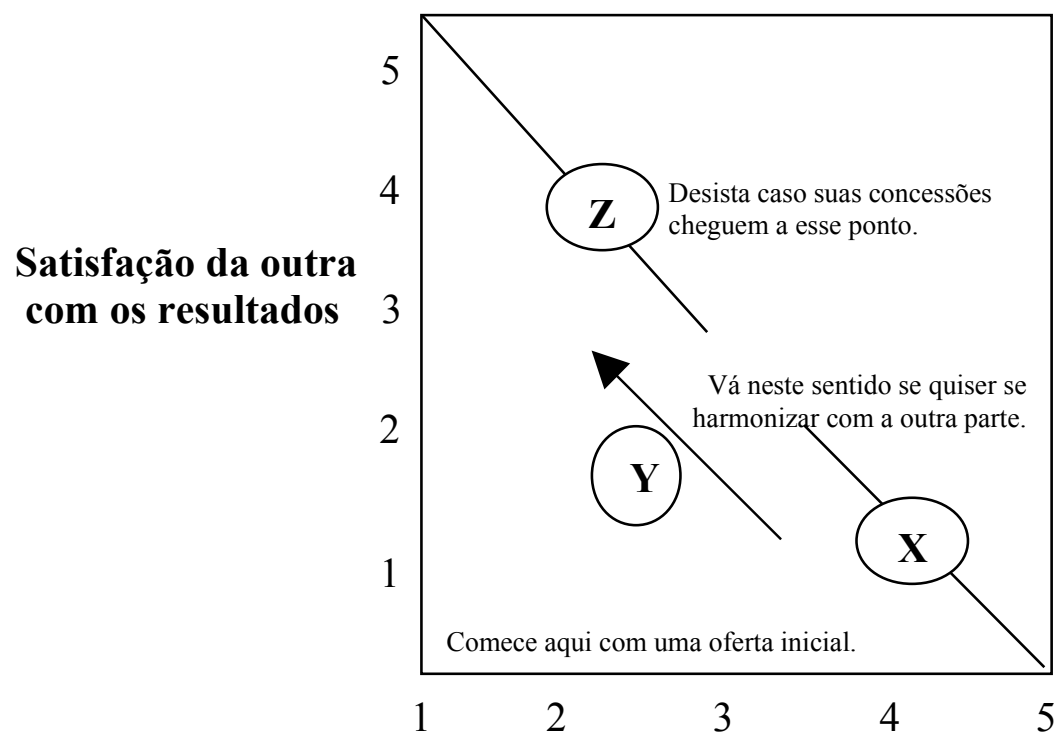

\section{Sua satisfação com os resultados}

Figura 2 - Seu campo de barganha.

Fonte: Lewicki e Hiam (2003).

A negociação com a outra parte dependerá da área limítrofe de barganha da outra parte. Havendo uma sobreposição entre as áreas limítrofes, a sua e a do outro, ou seja, o máximo que você está disposto a aceitar - a negociação é possível. Do contrário, não há negociação. 


\section{Estágio 4: Fechamento e implementação}

Este é o estágio final. É quando se revê o que foi acordo, prepara-se o contrato ou acordo, esclarece dúvidas e ambigüidades, e complementam-se idéias deixadas incompletas em discussões anteriores.

Os autores entendem que "é possível adaptar o jogo a cada situação de negociação simplesmente levando em consideração a importância relativa do resultado e do relacionamento. Cada negociação é diferente e seus resultados serão melhores se você adotar o estilo adequado a cada situação" (LEWICKI; HIAM, 2003, p. 139).

A partir dessas duas dimensões, Lewicki e Hiam (2003) propõem um modelo que retrata cinco estratégias de negociação que será melhor adequado dependendo da situação.
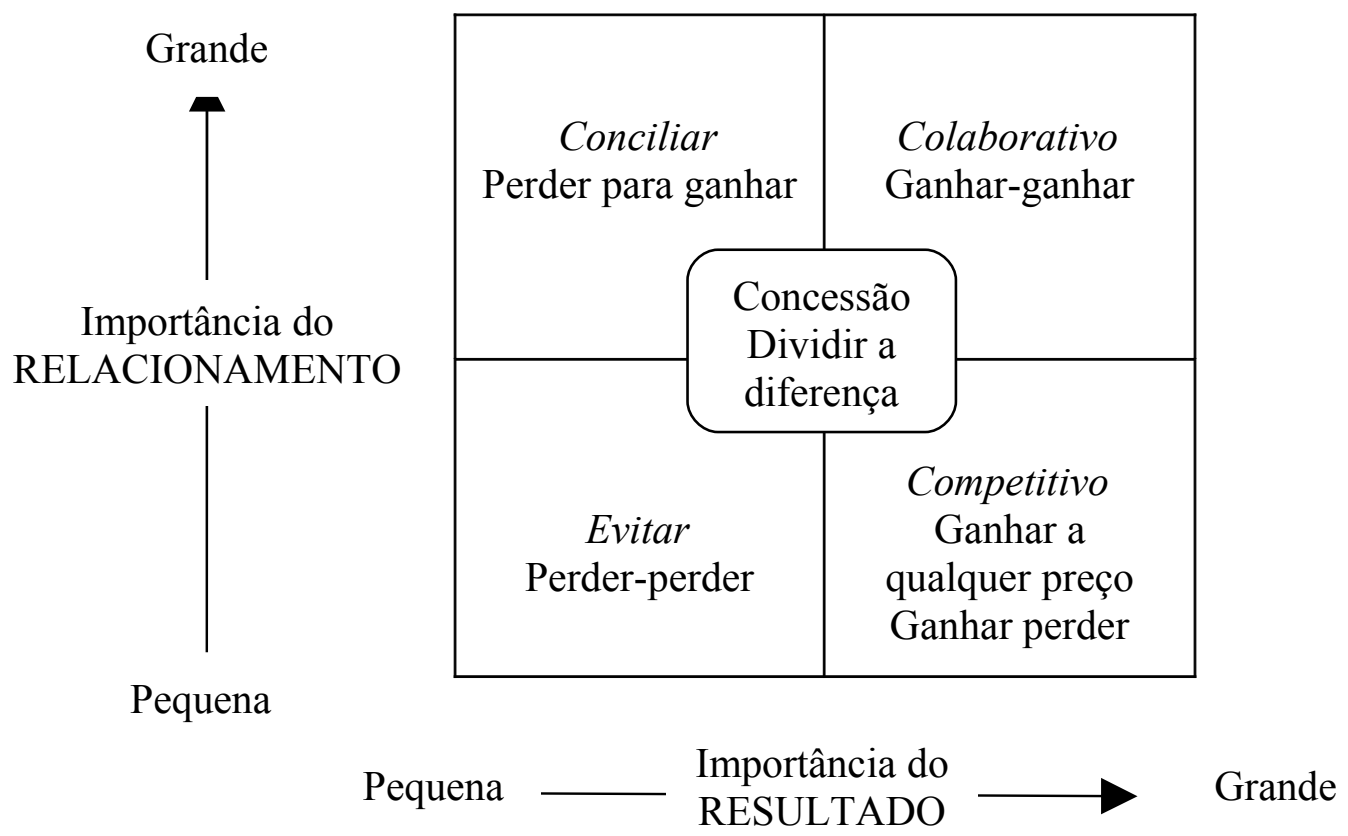

Figura 3 - Estratégias de Negociação.

Fonte: Lewicki e Hiam (2003).

1. Evitar (perder-perder). Suas prioridades, tanto para o relacionamento quanto para o resultado, são baixas. Nenhum desses dois aspectos da negociação é suficientemente importante para fazer com que se prossiga com o conflito. Pode-se aplicar essa estratégia retirando-se da negociação ou simplesmente evitando tal situação. 
2. Conciliar (perder para ganhar). Revela grande interesse pelo resultado e pouco pelo relacionamento. Essa estratégia é usada quando se quer ganhar a qualquer preço, desprezando o futuro desta possível relação.

3. Colaborativo (ganhar-ganhar). Representa uma estratégia em que o relacionamento e resultado são prioridades. Ao adotar essa estratégia, as partes procuram maximizar os resultados simultaneamente de modo a preservar ou melhorar o relacionamento. Alcança-se este resultado quando ambas as partes conseguem chegar a uma solução que supre suas respectivas necessidades.

4. Concessão (dividir a diferença). É uma abordagem usada em diversas situações. Por exemplo, é adotada quando as partes não conseguem uma boa colaboração, mas querem alcançar alguns resultados e/ou manter o relacionamento. Adota-se essa estratégia, também, quando as partes estão sob pressão de tempo e precisam chegar logo a um resultado. Cada parte cede um pouco para chegarem a um denominador comum.

Pesquisas revelam que pessoas em conflito têm preferências específicas por certas estratégias em situações de conflito (THOMAS, 1974, apud LEWICKI; HIAM, 2003). Essas preferências fazem com que as pessoas desenvolvam estilos também distintos, que adotam para abordar muitas situações.

No Quadro 1 são sintetizadas as perspectivas assumidas pelos autores para as interações possíveis entre negociadores de estilos diferentes. 


\begin{tabular}{|c|c|c|c|c|c|}
\hline Estilos & Evitar & Conciliar & Competir & Colaborar & Fazer Concessão \\
\hline Evitar & $\begin{array}{l}\text { As duas partes evitam atingir } \\
\text { suas metas nas questões e não } \\
\text { tomam atitudes que possam } \\
\text { estragar o relacionamento. }\end{array}$ & $\begin{array}{l}\text { O conciliador preocupa-se com } \\
\text { o que evita, principalmente } \\
\text { quanto ao relacionamento: o } \\
\text { que evita procura minimizar a } \\
\text { interação. }\end{array}$ & $\begin{array}{l}\text { O competidor dominará ou o } \\
\text { que evita escapará. } O \text { que evita } \\
\text { quer minimizar a interação, ao } \\
\text { passo que o competidor quer } \\
\text { interagir. }\end{array}$ & $\begin{array}{l}\text { O colaborador demonstra } \\
\text { interesse pelas questões das } \\
\text { duas partes e como } \\
\text { relacionamento, enquanto o } \\
\text { que evita tenta escapar. }\end{array}$ & $\begin{array}{l}\text { o concedente demonstra algum } \\
\text { interesse pelas questões das } \\
\text { duas partes e pelo } \\
\text { relacionamento: o que evita } \\
\text { tenta escapar. O concedente } \\
\text { pode desistir ou o que evita } \\
\text { pode participar. }\end{array}$ \\
\hline Conciliar & & $\begin{array}{l}\text { As duas partes evitam atingir } \\
\text { suas metas nas questões, } \\
\text { cedem às metas dos outros e } \\
\text { procuram manter o bom } \\
\text { relacionamento. }\end{array}$ & $\begin{array}{l}0 \text { competidor tenta atingir suas } \\
\text { metas nas questões, enquanto o } \\
\text { conciliador tenta fazê-lo feliz. } \\
\text { O competidor geralmente } \\
\text { ganha. }\end{array}$ & \begin{tabular}{|l|} 
O colaborador demonstra \\
interesse pelas questões das \\
duas partes e com o \\
relacionamento: o conciliador \\
procura satisfazer o \\
colaborador. O relacionamento \\
é sólido, mas o colaborador \\
tem mais chances de obter \\
melhores resultados.
\end{tabular} & $\begin{array}{l}\text { O concedente demonstra algum } \\
\text { interesse pelas questões das } \\
\text { duas partes e pelo } \\
\text { relacionamento: o conciliador } \\
\text { tenta satisfazer o concedente. } \\
\text { O relacionamento melhora e o } \\
\text { concedente pode induzir o } \\
\text { conciliador a procurar manter o } \\
\text { foco de alguma questão. }\end{array}$ \\
\hline Colaborar & & & $\begin{array}{l}\text { As duas partes fazem de tudo } \\
\text { para atingir suas metas nas } \\
\text { questões ignorando o } \\
\text { relacionamento e criando } \\
\text { conflitos, deconfinaça e } \\
\text { hostilidade. }\end{array}$ & \begin{tabular}{|l|} 
O colaborador demonstra \\
interesse pelas questões das \\
duas partes e com o \\
relacionamento, enquanto o \\
competidor geralmente ganha e \\
as duas partes tornam-se \\
competitivas.
\end{tabular} & \begin{tabular}{|l|} 
O concedente demonstra algum \\
interesse pelas questões das \\
duas partes e pelo \\
relacionamento, ao passo que o \\
competidor somente persegue \\
seus objetivos. $O$ competidor \\
geralemnte ganha e as duas \\
partes tornam-se competitivas.
\end{tabular} \\
\hline Fazer Concessão & & & & \begin{tabular}{|l|} 
As duas partes procuram \\
atingir seus objetivos, porém \\
demonstram interesse mútuo \\
pelas metas e manêm a \\
confiança, a abertura e um bom \\
relacionamento. \\
\end{tabular} & \begin{tabular}{|l|} 
O concedente demonstra algum \\
interesse. O colaborador \\
demonstra muito interesse \\
pelas questões das duas partes \\
e pelo relacionamento. No \\
mínimo, haverá boas \\
concessões ou um resultado \\
melhor. As duas partes \\
perseguem seus objetivos sem \\
exagero e procuram não "afetar \\
adversamente" o \\
relacionamento.
\end{tabular} \\
\hline
\end{tabular}

Quadro 1 - Interações Possíveis entre Negociadores de Estilos Diferentes. Fonte: Lewicki e Hiam (2003).

\subsubsection{A negociação para Fisher, Ury e Patton (1994)}

Para os autores a negociação é definida como “[...] É uma comunicação bidirecional concedida para chegar a um acordo, quando você e o outro lado têm alguns interesses em comum e outros aspectos". Três maneiras de negociar são citadas por esses autores tendo por base as questões: afabilidade e/ou aspereza. O negociador afável é aquele que quer evitar conflitos 
pessoais e, desse modo, faz concessões prontamente para chegar a um acordo. O negociador áspero encara qualquer situação como uma disputa de vontades na qual o lado que assume as posições mais extremadas e resiste por mais tempo obtém os melhores resultados.

Há uma terceira maneira de negociar, uma maneira que não é áspera nem afável, mas antes áspera e afável. O método da negociação baseada em princípios, desenvolvido no Projeto de Negociação de Harvard, "consiste em decidir as questões a partir de seus méritos, e não através de um processo de regateio centrado no que cada lado se diz disposto a fazer e não fazer" (FISHER; URY; PATTON, 2003, p. 16).

Este é o modelo de negociação proposto por esses autores, que pode ser resumido em quatro pontos fundamentais. Cada ponto versa sobre um elemento básico de negociação e sugere o que se deve fazer a respeito dele. A seguir, são apresentadas as características abordadas por cada ponto do método.

1) PESSOAS - separe as pessoas do problema

\section{Todo negociador tem dois tipos de interesse: na substância e na relação.}

Segundo os autores todo negociador quer chegar a um acordo que satisfaça seus interesses substantivos. É por isso que se negocia. Além disso, o negociador também tem interesses em seu relacionamento com o outro. Uma conseqüência fundamental do "problema das pessoas" na negociação é que o relacionamento entre as partes tende a confundir-se com suas discussões da substância. Tanto do lado que dá como que recebe, tendemos a tratar as pessoas e o problema como se fossem uma entidade única.

O processo de barganha posicional lida com esses interesses do negociador, tanto pelas substâncias como pelo bom relacionamento, colocando uma contra o outro. Neste sentido o negociador procura aumentar a probabilidade de que qualquer acordo atingido lhe seja favorável, começando numa posição extrema, aferrando-se obstinadamente a ela, iludindo a outra parte quanto a suas verdadeiras opiniões e fazendo pequenas concessões, apenas na medida necessária, para manter a negociação em andamento. O mesmo se aplica ao outro lado. Cada um desses fatores tende a interferir na pronta obtenção de um acordo. Quanto mais extremadas as posições iniciais e menores as concessões, maiores serão o tempo e o esforço despendidos para descobrir se o acordo é ou não possível. 


\section{Separe a relação da substância; lide diretamente com o problema pessoal}

Lidar com o problema substantivo e manter uma boa relação de trabalho não precisam ser metas conflitantes, caso as partes estejam empenhadas e psicologicamente preparadas para tratar cada um desses objetivos separadamente, segundo seus próprios méritos legítimos. Todos os diversos problemas das pessoas recaem numa das três categorias básicas: percepção, emoção e comunicação.

Percepção, compreender o pensamento da outra parte não é meramente uma atividade útil que irá ajudá-lo a solucionar seu problema. O pensamento do outro lado é o problema. O negociador tem que ter as habilidades de: pôr-se no lugar do outro; não deduzir das intenções do outro a partir de seus próprios medos; não culpar o outro do seu problema; discutir as percepções de cada um; buscar oportunidade de agir de maneira contraditória às percepções do outro; dar ao outro um interesse no resultado, certificando-se de que ele participa do processo e salvar as aparências: torne suas propostas compatíveis com os valores do outro.

Emoção, numa negociação particularmente numa disputa acirrada, os sentimentos podem ser mais importantes do que as palavras. Nesta técnica o negociador tem que ter as habilidades de: antes de mais nada, reconhecer e compreender as emoções, tanto do outro quanto as suas; explicitar as emoções e reconhecê-las na legitimidade; deixe que o outro lado desabafe; não reaja às explosões emocionais; use gestos simbólicos, a desculpa é um dos investimentos menos dispendiosos e mais recompensadores que se podem fazer.

Comunicação, sem comunicação não há negociação. A negociação é um processo de comunicação bilateral com o objetivo de se chegar a uma decisão conjunta. Há três grandes problemas na comunicação. Primeiro, os negociadores podem não falar um com o outro, ou, pelo menos, não de maneira a serem entendidos.

Mesmo quando se fala direta e claramente com o outro, talvez ele não escute. Este constitui o segundo problema da comunicação. O terceiro problema da comunicação são os malentendidos. Segundo os autores o que se pode fazer acerca desses três problemas de comunicação são: escute ativamente e registre o que está sendo dito; fale para ser entendido; fale sobre você mesmo, e não sobre o outro e fale com um objetivo.

\section{A prevenção é o que funciona melhor}

Os autores consideram que as técnicas para lidar com problemas de percepção, emoção e comunicação geralmente funcionam bem. Contudo, o melhor momento de lidar com os 
problemas das pessoas é antes de eles se tornarem problemas pessoais. Isso equivale também o jogo da negociação de maneira a separar o problema substantivo do relacionamento e a proteger os egos das pessoas envolvidas com as discussões substantivas. Para os autores um modo eficaz de as partes pensarem em si mesmas é como parceiros numa busca obstinada, lado a lado, de um acordo justo e vantajoso para ambos.

2) INTERESSES - concentre-se nos interesses, não nas posições

Os autores entendem que o problema básico de uma negociação não está nas posições conflitantes, mas no conflito entre as necessidades, desejos, interesses e temores de cada lado.

As posições tendem a ser concretas e explícitas; os interesses subjacentes a elas bem podem ser não expressos, intangíveis e talvez inerentes. As técnicas utilizadas na análise de como se deve proceder para compreender os interesses envolvidos são:

Pergunte "por que", consiste em colocar-se no lugar do outro. Examine cada posição que ele assume. A resposta com que você pode deparar é provavelmente, um dos interesses deles. E por outro lado pergunte “por que não?", a segunda pergunta é sobre a decisão que as pessoas do outro lado acham agora que você lhes está pedindo que tomem.

Em quase todas as negociações, cada uma das partes tem interesses, e não apenas um. Um erro comum no diagnóstico de uma situação de negociação consiste em supor que cada uma das pessoas do outro lado tem os mesmos interesses. Compreender os interesses desse negociador significa compreender a variedade de interesses um tanto diferentes que ele precisa levar em conta.

Os interesses mais poderosos são as necessidades humanas básicas, que incluem a seguir:

- segurança

- bem-estar econômico

- um sentimento de pertença

- controle sobre a própria vida.

Para discriminar os vários interesses faça uma lista, convêm discriminá-los à medida que eles ocorrem. A finalidade de negociar consiste em atender a seus interesses. A probabilidade que isso aconteça aumenta quando você os comunica. Parte da tarefa de convencer o outro lado de seus interesses consiste em estabelecer legitimidade desses interesses. Outro aspecto a ser 
observado é de reconhecer os interesses do outro como parte do problema. Coloque o problema antes de oferecer uma solução; olhe para frente, não para trás; seja objetivo, mas flexível, numa negociação você precisa saber aonde chegar, mas permanecer aberto às idéias novas; seja rigoroso com o problema e afável com as pessoas, apoiar os seres humanos do outro lado tende a aprimorar seu relacionamento e aumentar a probabilidade de que se chegue a um acordo. É a combinação de apoio e ataque que surge o efeito; isoladamente, qualquer um deles tende a ser insuficiente.

3) OPÇÕES - crie uma variedade de possibilidades antes de decidir o que fazer

Este método inicia-se com o diagnóstico da situação. Numa disputa, as pessoas costumam acreditar que sabem a resposta certa - sua opinião deve prevalecer. Numa negociação contratual, tendem igualmente a crer que a sua oferta é razoável e deve ser adotada, talvez com algum acerto quanto ao preço.

$\mathrm{Na}$ maioria das negociações, há quatro obstáculos fundamentais que inibem a invenção de uma multiplicidade de opções: (1) o julgamento prematuro; (2) a busca de uma resposta única; (3) a pressuposição de um bolo fixo, a negociação frequentemente se afigura como um jogo de "valor fixo"; (4) pensar que "resolver o problema deles é problema deles". Para superar essas limitações é preciso compreendê-las.

Os autores recomendam que para inventar opções criativas, precisa-se (1) separar o ato de inventar opções do ato de julgá-las; (2) ampliar as opções sobre a mesa, em vez de buscar uma resposta única; (3) buscar benefícios mútuo; e (4) inventar meios de facilitar as decisões do outro.

4) CRITÉRIOS - insista em que o resultado tenha por base algum padrão objetivo

Segundo os autores quanto mais se aplica padrões de imparcialidade, eficiência ou mérito científico ao problema específico, maior será sua probabilidade de produzir uma solução final sensata e justa.

Um exemplo dado pelos autores facilita o entendimento do método. Um episódio ocorrido durante a Conferência sobre a Lei do Mar ilustra as vantagens de usar critérios objetivos. A certa altura, a Índia, representando o bloco do Terceiro Mundo, propôs uma taxa inicial de sessenta 
milhões de dólares por sítio de exploração às empresas que viessem a fazer a mineração no fundo do mar. Os Estados Unidos rejeitaram a proposta, sugerindo que não houvesse nenhuma taxa inicial. Os dois lados fincaram o pé e a questão converteu-se numa disputa de vontades.

Foi então que alguém descobriu que o Instituto de Tecnologia de Massachusetts (MIT) havia elaborado um modelo para a economia da mineração no fundo do mar. Esse modelo, gradualmente aceito pelas partes como sendo objetivo, forneceu um modo de avaliar o impacto de qualquer proposta de taxa na economia da mineração. Quando o representante indiano indagou sobre o efeito de sua proposta, foi-lhe mostrado como a enorme taxa que propunha - pagável em cinco anos antes que a mina gerasse qualquer renda - tornaria praticamente impossível a mineração para qualquer empresa. Impressionado, ele anunciou que reconsideraria sua posição. Do outro lado, o modelo do MIT ajudou a instruir os representantes norte-americanos, cujas informações sobre o assunto eram basicamente restritas aos dados fornecidos pelas empresas de mineração. O modelo indicava que uma taxa seria economicamente viável. Em decorrência disso, os Estados Unidos também mudaram de posição.

Ninguém recuou e ninguém pareceu fraco, apenas lógico. Após uma negociação prolongada, as partes chegaram a um acordo provisório mutuamente satisfatório.

Para os autores conduzir uma negociação baseada em princípios envolve duas questões: como elaborar critérios objetivos e como empregá-los na negociação? Em termos mínimos, os critérios objetivos precisam independer da vontade de qualquer dos lados. Idealmente, para garantir um acordo sensato ${ }^{1}$, os critérios objetivos devem ser não apenas independentes da vontade, como também legítimos e práticos.

Depois de identificar alguns critérios e procedimentos objetivos, como fazer parte para discuti-los com o outro lado? Negocie com base nos méritos a seguir:

1.Formule cada questão como uma busca conjunta de critérios objetivos.

2. Pondere e permaneça aberto às reflexões sobre quais são os padrões mais apropriados e como devem ser aplicados.

3. Jamais ceda à pressão, mas tão-somente aos princípios.

As quatro proposições fundamentais da negociação baseada em princípios descritas (pessoas, interesses, opções e critérios) segundo os autores são importantes desde o momento em

\footnotetext{
${ }^{1}$ Os autores definem que um acordo sensato é aquele que atende aos interesses legítimos de cada uma das partes na medida do possível, resolve imparcialmente os interesses conflitantes, é duradouro e leva em conta os interesses da comunidade.
} 
que se chega um acordo, ou em que se decide interromper o esforço. Esse período pode ser dividido em três etapas: análise, planejamento e discussão.

Durante a fase de análise, tenta-se diagnosticar a situação - colher informações, organizálas e ponderar sobre elas. No estágio de planejamento, se lida com os mesmos quatro elementos pela segunda vez, gerando idéias e decidindo o que fazer. E por fim, na fase de discussão, quando as partes se comunicam entre si em busca de um acordo, os mesmos quatro elementos são os temas de discussão.

Em suma, em contraste com a barganha posicional, o método da negociação baseada em princípios, concentra-se nos interesses básicos, nas opções mutuamente satisfatórias e em padrões imparciais, resulta tipicamente em acordos sensatos. O método permite que se chegue a um consenso gradual numa decisão conjunta, eficientemente, sem todos os custos transacionais de aferrar-se a posições apenas para se ter que 'arrancar-se' delas depois. E separar as pessoas do problema permite que se lide direta e empaticamente como o outro negociador como um ser humano, possibilitando assim um acordo amigável.

Em resumo os dois modelos apresentam abordagens parecidas na análise de um processo de negociação. O que diferencia é a estrutura de análise destas abordagens. No caso de Lewicki e Hiam a negociação é vista em quatro estágios: preparação, inicial, barganha e implementação. Para Fisher, Ury e Patton cada ponto da negociação versa sobre um elemento básico: pessoas, interesses, opções e critérios. Conforme se pôde inferir do relato dos autores é que no processo de negociação as ações são movidas por um propósito, e os interesses das partes devem ser mapeados e planejados, com o objetivo de se estabelecerem ações, estratégias para um melhor diagnóstico da negociação. Apesar de interesses conflitantes, as partes têm sempre interesses comuns, mesmo que seja apenas querer o sucesso do empreendimento maior do qual fazem parte.

O ponto central dessas duas visões é que a primeira focaliza o processo da negociação e a segunda a dimensão subjetiva da negociação. Portanto, a primeira vê o fluxo para se chegar a um resultado e a segunda se preocupa mais com os autores envolvidos na negociação.

Nos tópicos seguintes serão apresentados o referencial teórico e a aplicação no campo organizacional dos indicadores de gestão organizacional: clima organizacional e indicadores de desempenho. 


\subsection{Indicadores de Gestão Organizacional}

Os indicadores de gestão organizacional a serem tratados neste tópico são o clima organizacional e os indicadores de desempenho.

\subsubsection{Clima Organizacional}

O clima organizacional é uma variável que influi diretamente na produtividade, pois o grau de salubridade de uma organização depende de sua atmosfera psicológica. Esta atmosfera é fruto do conjunto de percepções das pessoas que compartilham seu dia-a-dia com a organização.

O clima organizacional é definido por Abbey e Dickson (1983, apud PINHEIRO, 2002) como a qualidade de um ambiente interno de uma organização, que resulta do comportamento e conduta dos seus membros, serve como uma base para interpretar a situação e age, também, como uma fonte de pressão direcionando as atividades. Na mesma linha seguem Isaksen et al. (2000, apud PINHEIRO, 2002), associando-o à repetição de um modelo padrão de comportamento, atitude e sentimento, que caracteriza a convivência na organização. No nível individual de análise, o conceito é chamado de clima psicológico e se refere às percepções dos modelos de comportamento - avaliações cognitivas feitas por um indivíduo dos atributos do ambiente em termos daqueles que têm mais valor e significado pessoal para si próprio. Quando as avaliações são consideradas em conjunto, o conceito é denominado de clima organizacional, baseado na crença que as pessoas na organização compartilham objetivamente suas percepções das características da convivência na organização. Embora o clima seja percebido por indivíduos de dentro do ambiente de trabalho, ele existe independentemente destas percepções e é considerado um atributo da organização entretanto a sua medida é feita, quase sempre, a partir da percepção ou da cognição dos empregados da organização.

\subsubsection{Aplicações no Campo Organizacional}

O conhecimento do clima organizacional, afirma Silva (1994, apud HERNANDEZ e MELO, 2003) proporciona uma visão do estado da organização e de suas relações com outras variáveis organizacionais e individuais, o que possibilita ajustar as necessidades entre estas duas 
dimensões, tornando mais provável a execução das metas de trabalho. Este ajuste é mais fácil quando se conhecem as relações com outras variáveis e pode-se intervir, a partir desta compreensão, no sentido de produzir as modificações desejadas.

O autor ainda assevera que o clima organizacional tem impactos nos processos de comunicação, tomada de decisões, solução de problemas, manejo de conflitos, atitudes e motivação, satisfação e execução. Deste modo, se modificarmos, através da intervenção, o clima de uma organização, ou se introduzirmos trocas em elementos que interferem no clima, poderá incidir nos resultados em forma de inovação, aproveitamento e satisfação.

\subsubsection{Indicadores de Desempenho}

Os indicadores de desempenho compreendem os dados que quantificam as entradas (recursos ou insumos), os processos, as saídas (produtos), o desempenho de fornecedores e a satisfação das partes interessadas. São usados para acompanhar o desempenho ao longo do tempo e podem ser classificados em: simples (decorrentes de uma única medição) ou compostos; diretos ou indiretos, em relação à característica medida; e direcionadores ou resultantes. Um indicador de desempenho é um dado numérico a que se atribui uma meta e que é trazido, periodicamente, à atenção dos gestores de uma organização. Eles se constituem no elo entre as estratégias e o resultado das atividades, devendo evidenciar o valor agregado às partes interessadas (Fundação Nacional da Qualidade - FNQ, 2008).

Para Marceli (1998 apud POPADIUK et.al., 2006), o projeto básico de um sistema de indicadores deve refletir os objetivos estratégicos da empresa. Nesse caso, o Balanced Scorecard se constitui em um sistema equilibrado de indicadores de desempenho, que reflete várias perspectivas da empresa e motiva as equipes na medida em que se aproxima dos objetivos e ações operacionais.

Kaplan e Norton (1997) definem o Balanced Scorecard como um conjunto de indicadores que proporcionam uma visão rápida e abrangente da empresa, mesclando quatro perspectivas: financeira, de clientes, interna e de aprendizagem e crescimento. A vantagem dessa metodologia é centrar-se na estratégia e não nos controles, traduzindo visões e estratégias em objetivos e planos de ação. 
Os indicadores sobre as quatro perspectivas do Balanced Scorecard podem ser medidas conforme o apresentado no Quadro 2 abaixo.

\begin{tabular}{|ll|}
\hline \multicolumn{1}{|c|}{ Perspectiva } & \multicolumn{1}{c|}{ Medidas genéricas } \\
\hline Financeira & Retorno sobre o investimento, valor econômico agregado, lucratividade, aumento/mix de receita, \\
& produtividadeda redução de custos. \\
Do cliente & Satisfação, retenção, participação de conta e aquisição de novos clientes. \\
Interna & Qualidade, tempo de resposta, custo e lançamento de novos produtos. \\
Aprendizagem e crescimento & Satisfação dos funcionários e disponibilidade dos sistemas de informação. \\
\hline
\end{tabular}

Quadro 2 - Indicadores sobre as quatro perspectivas do Balanced Scorecard.

Fonte: Kaplan e Norton (1997, p. 44)

\subsubsection{Aplicações no Campo Organizacional}

A análise e a mensuração de desempenho podem ser definidas literalmente como o processo de se quantificar uma ação, no qual mensuração é o processo de quantificação e a ação é aquilo que provoca o desempenho, afirma Neely (1995, apud PACE et.al. 2003).

Quando os processos são medidos, podemos revelar informações sobre a sua realidade de resultados, habilitando o gestor a tomar as decisões mais apropriadas. As medidas são a fonte mais segura e insuspeita para tomar decisões inconscientes. Por outro lado o feeling e a sensibilidade são atributos da natureza essencialmente subjetiva e, portanto de cunho meramente emocional. Sem dúvida, esses atributos são também indispensáveis para chegarmos às decisões acertadas. Todavia, são as medidas que agregarão o caráter mais racional e objetivo às decisões (MARANHÃO 2004, p. 69).

Maranhão (2004, p.69) “complementa que são as medidas que permeiam as comparações e, em boa parte, instrumentalizam o gestor para reconhecer e atribuir o mérito devido, pelo bom ou pelo mau resultado alcançado".

Um bom administrador controla o desempenho dos sistemas sob sua responsabilidade com a ajuda de medidas de desempenho. Como esses sistemas se desenvolveram e como evoluíram pode ser mais bem compreendido por meio do conhecimento das forças que os moldaram, afirma Kaplan (1997), sendo raro encontrar-se um único fator como responsável por determinada ação. Normalmente, ocorre uma combinação de fatores e forças que levam a organização a dirigir-se para determinada direção.

No tópico seguinte serão apresentados os procedimentos metodológicos para realização deste estudo. 


\section{METODOLOGIA}

A metodologia deste estudo busca conhecer a realidade da organização pesquisada. Adiante, seguem-se as descrições minuciosas a respeito dos passos e estruturação do presente objeto.

\subsection{Tipo de Pesquisa}

O método de pesquisa utilizado foi o estudo de caso. Yin define este método como "uma investigação empírica que investiga um fenômeno contemporâneo dentro de seu contexto de vida real, especialmente quando os limites entre o fenômeno e o contexto não são claramente definidos...” (YIN, 2005, p. 32-33). Ademais, o estudo de caso parece ser a melhor estratégia a ser adotada porque os objetivos desta pesquisa vão ao encontro da essência de um estudo de caso, que é a de tentar "esclarecer uma decisão ou um conjunto de decisões: o motivo pelo qual foram tomadas, como foram implementadas e com quais resultados" (SCHRAMM apud YIN, 2005, p.31).

Para Yin (2005) o método do estudo de caso é adequado para responder a questões do tipo “como" e "porque", que são explicativas e tratam de relações operacionais que ocorrem ao longo do tempo mais do que frequências ou incidências.

\subsection{Unidade de análise}

A unidade de análise é uma organização. Serão avaliados os acordos coletivos de trabalho dos Correios, sendo a coleta e avaliação dos dados dos indicadores de gestão organizacional neste estudo, especificamente, dos Centros de Distribuição de Encomendas (CEE) da ECT.

A rede logística dos Correios é composta por quatro grandes unidades: atendimento, tratamento, transporte e distribuição. Na última etapa da cadeia logística encontram-se os Centros de Entrega de Encomendas que são, por sua vez, as unidades responsáveis pela coleta e entrega de encomendas na área urbana, ou seja, são as unidades que fazem com que as encomendas cheguem ao destinatário. 
O Departamento Operacional de Encomendas (DENCO) é o órgão responsável pela gestão dos CEE. Atualmente são 105 unidades instaladas em todo o Brasil, nas chamadas Diretorias Regionais (DR).

\subsection{Instrumento de Coleta de Dados}

As informações para coleta foram por meio do uso de múltiplas fontes de evidência: pesquisa documental, por meio de consulta aos registros: manuais internos, arquivos dos acordos coletivos disponíveis na intranet, relatórios de resultado dos indicadores de clima e da ferramenta denominada Data Warehouse $(D W)$ para apuração dos indicadores de desempenho operacional, e da explanação por parte de alguns integrantes das equipes que fizeram e fazem parte do processo de negociação coletiva na empresa, corroborando certos fatos acontecidos, registrados nos documentos. Estes documentos foram suporte para as questões analisadas ao longo do trabalho sobre os acordos coletivos de trabalho e os indicadores de Gestão Organizacional como: o clima e os indicadores de desempenho operacional.

A pesquisa de registros em arquivo, na visão de Yin (2005) pode ser utilizada em conjunto com outras fontes de informação ao se produzir um estudo de caso. Ao contrário das evidências documentais os registros podem ser tão importantes que podem se transformar no objeto de uma análise quantitativa e de recuperação.

Neste estudo utilizou-se a entrevista semi-estruturada. As entrevistas foram espontâneas e assumiram o caráter de uma conversa informal, sendo um dos propósitos principais corroborar certos fatos.

\subsection{Procedimentos de Coleta de Dados}

A realização da pesquisa precedeu da análise aos documentos internos da organização, cartilhas dos acordos coletivos, relatórios de resultados do clima organizacional e dos indicadores de desempenho organizacional coletadas no DW.

A entrevista foi realizada e registrada pessoalmente com o coordenador do processo de negociação coletiva na empresa e outro integrante que fez parte do processo de negociação coletiva nos Correios. 


\subsection{Análise de Dados}

Segundo Yin (2005) a análise de dados consiste em examinar, categorizar, classificar em tabelas, testar ou, do contrário recombinar as evidências quantitativas e qualitativas para tratar as proposições iniciais de um estudo. "A familiaridade com várias ferramentas e técnicas de manipulação é muito útil, mas cada estudo de caso deve se esforçar para ter uma estratégia analítica geral - estabelecendo prioridades do que ser analisado e por que" (YIN 2005, p. 137).

A análise foi feita baseando-se em proposições teóricas. A proposição ajuda a pôr em foco certos dados e ignorar outros. Ela também ajuda a organizar todo o estudo de caso e a definir explanações alternativas a serem examinadas. "Proposições teóricas sobre as relações causais respostas a questões do tipo "como" e "por que" - podem ser muito úteis para orientar a análise do estudo de caso" (YIN 2005, p. 140-141).

Os dados analisados referem-se a 70 Centros de Entrega de Encomendas - CEE, das 105 unidades instaladas. O total de Diretorias Regionais - DR e unidades, Quadro 3, é resultado da quantidade de unidades que tiveram seus questionários válidos na pesquisa de clima e que tinham sido instaladas até 2005, considerando que neste período os resultados da pesquisa de clima organizacional $\left(2^{\circ}\right.$ ciclo) são individualizados por unidade e se inicia a apuração automática do desempenho da distribuição nacional do serviço SEDEX.

Para este trabalho avaliou-se dentre os objetos postais (tais como cartas, malotes, impressos, encomendas SEDEX e PAC (serviço de remessa econômica de mercadorias com entrega domiciliar), etc.) o indicador de desempenho do serviço SEDEX distribuídos pelos CEE, pelo volume de objetos entregues e de receita, o que o transforma no principal serviço da ECT.

De modo a manter o sigilo das informações dos CEE divulgados neste estudo, as unidades serão denominadas por letras e serão agrupadas em 5 grupos por Diretoria Regional, equivalente ao Estado da Federação, conforme apresentado no Quadro 3, segundo as características comuns operacionais. Esta classificação visa auxiliar na apresentação e análise dos resultados, tanto dos acordos coletivos e dos indicadores organizacionais: clima e desempenho operacional. 


\begin{tabular}{|c|l|c|}
\hline Grupo & \multicolumn{1}{|c|}{ DR } & $\begin{array}{c}\text { Quantidade de } \\
\text { CEE Avaliados }\end{array}$ \\
\hline 1 & SPM, SPI, RJ, MG e ES & 37 \\
\hline 2 & BSB, GO, MS, PR, RS e SC & 18 \\
\hline 3 & AL, BA, CE, PB, PE, RN e SE & 09 \\
\hline 4 & AM, AP, PA, PI e RR & 04 \\
\hline 5 & MT e RO & 02 \\
\hline Total & $\mathbf{2 5}$ & $\mathbf{7 0}$ \\
\hline
\end{tabular}

Quadro 3 - Quantidades de CEE avaliados classificadas por grupo Fonte: Documentos internos da ECT.

No bloco a seguir serão descritos os resultados do indicador clima organizacional referente aos ciclos de 2005, 2007 e 2008 e os resultados do indicador desempenho da distribuição nacional do serviço SEDEX, relativo aos mesmos períodos do clima. 


\section{RESULTADOS}

Neste capítulo é contextualizada a evolução do processo de negociação coletiva nos Correios, com destaque para os principais pontos que evidenciam o seu aprimoramento. Da mesma forma são apresentados os dois indicadores considerados na pesquisa: clima organizacional e desempenho, com a evolução dos seus resultados.

\subsection{O Processo de Negociação Coletiva na ECT}

Os acordos coletivos de trabalho (ACT) analisados foram dos seguintes anos: 2002/2003, 2004/2005, 2006/2007 e 2008/2009. Estes acordos estão disponibilizados na página da intranet da ECT. No Apêndice A deste trabalho estão o comparativo das cláusulas dos referidos acordos coletivos.

Atualmente o processo de negociação coletiva na ECT é coordenado pelo Comitê Permanente de Relações do Trabalho (CPRT), composto de 7 (sete) integrantes com o auxílio das Assessorias de Gestão das Relações de Trabalho (ASGET) nas Diretorias Regionais (DRs), que tem o objetivo de planejar, estabelecer estratégias, negociar e celebrar acordos com as entidades representativas dos empregados, em relação aos temas que afetam a vida da organização no que concerne a remuneração dos empregados, fornecimento de benefícios, condições de trabalho, relacionamento entre lideranças e equipes, condições de saúde, segurança e demais temas que também afetam a vida da empresa e dos empregados.

A empresa tem como desafio a busca permanente do diálogo para atingir altos níveis de relacionamentos com as entidades representativas dos empregados, preservar as políticas de governo, as necessidades da sociedade demandante dos serviços prestados pela empresa, valorização da organização, interesses dos empregados, dos clientes e fornecedores.

A primeira greve nos Correios ocorreu em 1978 na Diretoria Regional de Minas Gerais, sendo decretada em 1985 a paralisação de empregados na Diretoria Regional de São Paulo. Este primeiro momento de negociação coletiva era de inexperiência, havia um impasse nas negociações indo a dissídio coletivo, que consiste no "processo judicial destinado à solução dos conflitos coletivos pela via jurisdicional" (SIQUEIRA 1998, p. 54). Neste período a greve é declarada, ocorrem demissões e são criadas as Associações dos Empregados da ECT. 
No segundo momento já havia um processo de aprimoramento, com a preocupação do treinamento gerencial e das questões trabalhistas. Com a Constituição de 1988 (CF/88) as associações de empregados se transformam em sindicatos e a empresa passou a instituir a Comissão de Negociação. Tanto a empresa quanto os sindicatos começam a investir nos seus quadros de pessoal. O primeiro acordo coletivo de trabalho (ACT) é assinado em dezembro de 1988.

O cenário atual percebe-se a busca pela profissionalização no tratamento das questões sindicais, com atuação nos diversos aspectos que envolvem o clima organizacional. A estrutura organizacional, também, passou por ajustes, sendo criada em:

1989 - Seção de Relações Sindicais;

1990 - Função de Assessor de Relações Sindicais;

1993 - Assessorias de Relações Sindicais (ARSIN);

2000 - ARSIN passa a ser uma seção da Gerência das Relações Sindicais e do Trabalho (GERET);

2004 - Departamento de Gestão de Relações Sindicais e do Trabalho (DEGET), que contava com três divisões (Divisão de Negociações Sindicais, Gerenciamento do Clima Organizacional e Suporte à Comunicação Interna) e das Assessorias de Gestão das Relações Sindicais e do Trabalho nas regionais (ASGET);

2008 - Extinção do DEGET criação do Departamento de Desenvolvimento Organizacional e de Pessoas (DESEN) e do Comitê Permanente de Relações do Trabalho (CPRT).

A negociação coletiva é a fase que antecede os instrumentos normativos (acordos coletivos, convenções coletivas, contratos coletivos). Nos Correios ela ocorre exclusivamente em períodos certos, com início em junho até agosto, que corresponde a data-base, período limite de desenvolvimento das negociações.

As partes envolvidas no processo de negociação coletiva são: representando os empregados - o sindicato dos trabalhadores, organizado em um Comando Nacional da Federação Nacional dos Trabalhadores em Empresas de Correios e Telégrafos e Similares (FENTECT), com 7 (sete) integrantes, representantes dos 34 (trinta e quatro) sindicatos nacionais. Cabe aos sindicatos aprovar a pauta de reivindicações, que desde 2002 é composta de 72 (setenta e dois) itens. Representando a empresa - a Comissão Nacional de Negociações Trabalhistas da ECT. A 
empresa é composta de 28 Diretorias Regionais (DR) e da Administração Central (AC) localizada na cidade de Brasília - Distrito Federal.

O grupo 1 (ES, MG, RJ, SPI e SPM) e grupo 2 (BSB, GO, MS, PR, RS e SC) concentram as bases das representações dos sindicatos, de onde saem as diretrizes durante o processo de negociação coletiva, mobilizando todo o país na decretação e agitações de eventos durante a fase de renovação do acordo coletivo de trabalho.

As mobilizações de empregados ocorrem em todo territorial nacional. Elas acontecem segundo o calendário definido na $1^{\text {a }}$ reunião dos sindicatos. Nesta fase é definida e negociada, em assembleias, a pauta de reivindicações que após tratativas é protocolada na ECT. A partir do recebimento oficial do documento, a empresa inicia o processo de análise dos itens constantes na pauta.

Durante a fase de negociação a Comissão Nacional de Negociações Trabalhistas da ECT se reúne para avaliação e discussão criteriosa da pauta de reivindicações, levantamento dos custos, possibilidades de atendimento da pauta conforme a situação financeira da empresa, as diretrizes do governo federal e as tendências do mercado de trabalho para envio da proposta para aprovação pela Diretoria da ECT.

A etapa seguinte, caso o processo não vá a dissídio, passa pelo Ministério das Comunicações e, posteriormente, pelo Departamento de Coordenação e Controle das Empresas Estatais (DEST) que define os balizadores econômicos. Caso a solução do conflito coletivo de trabalho seja por intermédio do Poder Judiciário, o TST, as audiências vão para conciliação (acordo judicial) e julgamento (sentença). Por fim o acordo é protocolado no Ministério do Trabalho e publicado no Diário Oficial da União.

Durante as negociações a empresa procura manter-se atualizada, atenta à mobilização das equipes e às atividades sindicais, dentro e fora das unidades. Há uma intensificação da comunicação interativa com as equipes, utilizando de informativos que permitem aos empregados acompanharem as negociações, com rapidez e de forma ativa, a exemplo do "Plantão do acordo" e do "Primeira Hora". Outro mecanismo é o Sistema de Monitoramento do Cenário de Contingência (SMON), desenvolvido em 2004, onde são registradas todas as informações das unidades operacionais, do chão de fábrica, com as informações de movimentos paredistas, efetivo, carga de trabalho, etc. utilizado para armazenamento, recuperação e disseminação de informações gerenciais sobre o cenário das relações de trabalho na ECT. 
A possibilidade da decretação do direito de greve, assegurado na $\mathrm{CF} / 88$, art. $9^{\circ}$ a qual compete aos trabalhadores decidir sobre a oportunidade de exercê-lo e sobre os interesses que devam por meio dele defender, gera algumas ações empreendidas pela organização, nas fases prégreve, durante e pós-greve, resumidas no Quadro 4, a seguir:

\begin{tabular}{|c|c|c|}
\hline Pré-greve & Durante a Greve & Pós-greve \\
\hline $\begin{array}{l}\text { Certificar-se de que os demais gestores e os } \\
\text { demais empregados da Unidade estejam } \\
\text { orientados sobre a posição da Empresa diante de } \\
\text { uma possível greve; }\end{array}$ & Manter atuante o sistema de comunicação ; & $\begin{array}{l}\text { As ações do gestor devem estar coerentes com } \\
\text { as orientações da Empresa; }\end{array}$ \\
\hline $\begin{array}{l}\text { Avaliar, permanentemente, a disposição da equipe } \\
\text { em aderir ao movimento grevista; }\end{array}$ & $\begin{array}{l}\text { Não responder a provocações, agindo com } \\
\text { autocontrole; }\end{array}$ & $\begin{array}{l}\text { Tratar os empregados que estiveram em greve, } \\
\text { inclusive os dirigentes e delegados sindicais, com } \\
\text { respeito e sem discriminação; }\end{array}$ \\
\hline $\begin{array}{l}\text { Orientar individual e coletivamente os } \\
\text { empregados sobre os reflexos negativos de uma } \\
\text { paralisação; }\end{array}$ & $\begin{array}{l}\text { Chegar ao local de trabalho com antecedência, } \\
\text { conforme orientações da Empresa; }\end{array}$ & $\begin{array}{l}\text { Desativar progressivamente o esquema } \\
\text { emergencial, de acordo com as orientações da } \\
\text { Empresa; }\end{array}$ \\
\hline $\begin{array}{l}\text { Buscar apoio junto às lideranças naturais da } \\
\text { equipe para orientar os colegas; }\end{array}$ & $\begin{array}{l}\text { Evitar confrontos físicos e troca de ofensas } \\
\text { morais; }\end{array}$ & $\begin{array}{l}\text { Avaliar as causas e as consequências da } \\
\text { paralisação. }\end{array}$ \\
\hline $\begin{array}{l}\text { Buscar apoio junto aos superiores para fortalecer } \\
\text { a comunicação com a equipe; }\end{array}$ & $\begin{array}{l}\text { Documentar ações praticadas pelas lideranças do } \\
\text { movimento de greve, que comprometam o direito } \\
\text { de livre acesso ao trabalho, a preservação da } \\
\text { pessoa e do patrimônio público; }\end{array}$ & \\
\hline \multirow[t]{5}{*}{$\begin{array}{l}\text { Destacar que o livre acesso ao trabalho, a } \\
\text { preservação da pessoa e do patrimônio público, } \\
\text { são direitos legais (Lei } 7783 / 89 \text { - Lei de greve ). }\end{array}$} & $\begin{array}{l}\text { Controlar o acesso às dependências da Empresa, } \\
\text { permitindo a entrada daqueles que se } \\
\text { apresentarem para o trabalho; }\end{array}$ & \\
\hline & $\begin{array}{l}\text { Manter os gestores superiores informados sobre a } \\
\text { situação na unidade, através do SMON; }\end{array}$ & \\
\hline & $\begin{array}{l}\text { Manter os empregados, inclusive os grevistas, } \\
\text { informados sobre as ações adotadas pela } \\
\text { Empresa para assegurar a prestação dos serviços } \\
\text { à população; }\end{array}$ & \\
\hline & $\begin{array}{l}\text { Trabalhar em permanente regime de plantão, com } \\
\text { revezamento entre os gestores; }\end{array}$ & \\
\hline & $\begin{array}{l}\text { As declarações a órgãos de imprensa serão } \\
\text { centralizadas pelas ASCOMs. }\end{array}$ & \\
\hline
\end{tabular}

Quadro 4 - Ações empreendidas pela organização pré, durante e pós-greve.

Fonte: Documentos internos da ECT.

Nos Correios o instrumento normativo resultante da negociação é o acordo coletivo, que tem vigência de 12 meses. Como não existem empresas similares no mercado, a ECT procura se preparar para o processo de negociação avaliando as tendências do mercado, as expectativas e o bem-estar dos empregados, realizando "benchmarking" com outros órgãos do governo, bem como monitorando, ao longo do ano, com o auxílio das ASGTEs, o clima organizacional nas unidades operacionais, assim como a iminência de conflitos.

O modelo de negociação adotado é o ganha-ganha, sendo percebida pelos representantes da ECT de 10 (dez) anos para cá, consolidando-se nos últimos 5 (cinco) anos. No início das 
negociações nos Correios o processo era marcado por conflitos, mesmo depois da CF/88 havia uma relação de medição de forças.

Quanto ao processo de negociação, fazendo um comparativo com as abordagens apresentadas pelos autores no referencial teórico com as práticas adotadas pela ECT durante as fases da negociação coletiva percebe-se uma identificação com a proposta de Lewicki e Hiam, conforme se pode verificar no Quadro 5.

\begin{tabular}{|c|c|c|}
\hline Estágio proposto pelos autores & Descrição do estágio & Aplicações da ECT \\
\hline Preparação & \begin{tabular}{|l} 
coleta de informações - definição \\
dos objetivos de ambas as \\
partes; planejamento - delinear a \\
direção que pretende-se numa \\
negociação.
\end{tabular} & $\begin{array}{l}\text { A ECT busca pela profissionalização no tratamento } \\
\text { das questões sindicais, com atuação nos diversos } \\
\text { aspectos que envolvem o clima organizacional. Ela } \\
\text { procura prepara-se para o processo de negociação } \\
\text { avaliando as tendências do mercado, as expectativas e } \\
\text { o bem-estar dos empregados, realizando } \\
\text { "benchmarking" com outros órgãos do governo, bem } \\
\text { como monitorando ao longo do ano com o auxílio das } \\
\text { ASGTEs, localizadas em todas as diretorias regionais, } \\
\text { o clima organizacional nas unidades operacionais, a } \\
\text { iminência de conflitos, bem como apoiar em âmbito } \\
\text { regional as Relações Sociais do Trabalho e Sindicais. }\end{array}$ \\
\hline Inicial & $\begin{array}{l}\text { exposição de argumentos; ouvir } \\
\text { a outra parte para que se possa } \\
\text { contra-aumentar }\end{array}$ & $\begin{array}{l}\text { A partir do recebimento oficial da pauta de } \\
\text { reinvidicações por parte do Comando Nacional da } \\
\text { FENTECT, os Correios começam o processo de } \\
\text { análise dos itens constantes na pauta. }\end{array}$ \\
\hline Barganha & $\begin{array}{l}\text { dentro da área de } r \text { barganha } \\
\text { incluem-se: partida, meta, } \\
\text { resistência ou a desistência; em } \\
\text { uma negociaçao, as partes } \\
\text { normalmente sabem que as } \\
\text { solicitações } \quad \text { iniciais rão } \\
\text { exageradas e que uma das partes } \\
\text { terá que fazer concessões para } \\
\text { chegar a um acordo. }\end{array}$ & 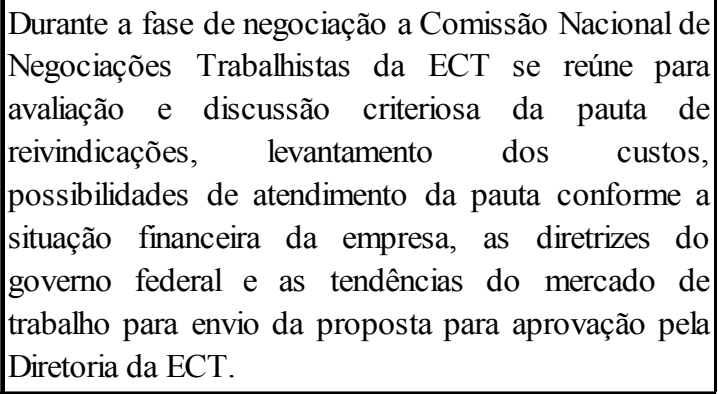 \\
\hline Fechamento e de Implantação & $\begin{array}{l}\text { estágio final, revê o que foi } \\
\text { acordado, prepara-se para o } \\
\text { contrato ou acordo. }\end{array}$ & $\begin{array}{l}\text { Caso o processo não vá a dissídio, passa pelo } \\
\text { Ministério das Comunicações e, posteriormente, pelo } \\
\text { DEST que define os balizadores econômicos. Caso a } \\
\text { solução do conflito coletivo de trabalho seja por } \\
\text { intermédio do Poder Judiciário. Por fim o acordo é } \\
\text { protocolado no MT e publicado no DOU. Nos } \\
\text { Correios o instrumento normativo resultante da } \\
\text { negociação é o acordo coletivo, que tem vigência de } \\
12 \text { meses. }\end{array}$ \\
\hline
\end{tabular}

Quadro 5 - Etapas da negociação, comparativo entre a teoria e a aplicação pela ECT.

Fonte: Documentos internos da ECT. 
Quanto ao acompanhamento dos acordos coletivos, o Apêndice A traz de forma sintética as cláusulas dos ACT, agrupadas por blocos, segundo a descrição do item: benefício (segue a classificação definida pela empresa), econômico (acréscimo monetário), social (relações pessoais) e trabalho (relações de trabalho). Neste apêndice, consta o comparativo das cláusulas dos acordos coletivos de 2002/2003 a 2008/2009 da ECT do que alterou, incluiu, exclui e manteve de um acordo para outro.

Os benefícios oferecidos pela organização apresentam uma constância nas alterações, em torno de $83 \%$, tais como assistência médica/hospitalar e odontológica, auxílio para filhos dependentes de cuidados especiais, reembolso-creche, saúde dos empregados e vale refeição/alimentação a cada nova negociação coletiva. As mudanças refletem, em parte, na revisão monetária dos benefícios que influenciam na qualidade de vida dos empregados.

No bloco econômico as cláusulas mantêm a mesma redação, não apresentando mudanças a cada novo acordo firmado. Destaque neste bloco são os itens que tratam da gratificação de quebra de caixa, concedida aos empregados que exerçam permanentemente as atividades de recebimento de pagamento de dinheiro à vista nas Agências de Correios, e reajuste salarial, uma das principais bandeiras levantadas pelos sindicatos durante o processo de negociação coletiva, sendo revistos a cada ano. O reajuste salarial dentre os demais itens da pauta de reinvidicações proposta pelo sindicato é o que representa maior impacto financeiro, normalmente com solicitações iniciais exageradas, e que exige uma parcela maior de tempo nas tratativas da negociação coletiva.

No campo social os resultados do ACT 2004/2005 demonstram o maior número de inclusões de cláusulas editadas, que representam avanços sociais nas relações de trabalho tais como: o desenvolvimento de programas educativos visando coibir e prevenir o assédio sexual e assédio moral. Implantação de políticas de orientação contra a discriminação racial, com apuração dos casos. Ampliação de 20\% das vagas para deficientes físicos em todos os concursos, quando o percentual de $10 \%$ conforme previsão da $\mathrm{CF} / 88$.

Assim como no bloco econômico, no campo do trabalho as cláusulas mantêm a mesma redação, não apresentam mudanças a cada novo acordo firmado. Os destaques são a inclusão da Comissão Interna de Prevenção de Acidentes - CIPA, com o funcionamento de mais de 600 CIPAs em todas as Diretorias Regionais, desde 2003, com uma quantidade superior ao previsto em Lei, reforçando a política de prevenção adotada pela empresa. E das medidas de segurança 
necessárias para preservar a segurança física dos empregados, clientes e visitantes que circulam em suas dependências e do aprimoramento das condições ergonômicas do ambiente de trabalho.

Como forma de avaliar as relações de trabalho nos Correios, a empresa passou a contar, a partir de 2004, com o processo de gestão do clima organizacional, que será detalhado no item seguinte.

\subsection{Clima Organizacional}

Um dos mecanismos utilizados pela organização para o diagnóstico da percepção dos empregados sobre as relações de trabalho nos Correios é a pesquisa de clima organizacional cujo resultado constitui uma das parcelas da Qualidade do Ambiente de Trabalho (QUAT) que compõe o conjunto dos 8 (oito) indicadores estratégicos da ECT, vinculado à perspectiva Pessoas, estruturada e sistematizada para aplicação nacional, desde 2004. O indicador é apurado de forma global (ECT, Administração Central e Diretorias Regionais). Os resultados são individualizados por unidades, com exceção da pesquisa de 2004 cujos resultados foram por DR, favorecendo a análise do clima organizacional nas diferentes áreas do processo produtivo dos Correios: atendimento, distribuição, tratamento/encaminhamento e administrativa. Este processo encontra-se normatizado nos manuais da empresa.

A pesquisa está inserida no processo de gestão do clima que é desenvolvido por meio de ciclos definidos. Cada ciclo tem a duração aproximada de 18 (dezoito) meses e é composto por 5 (cinco) macro-etapas descritas no Quadro 6.

A duração de cada ciclo foi estabelecida levando em conta a magnitude do processo de pesquisa e gestão do clima organizacional na ECT. São mais de 108.000 empregados e milhares de unidades envolvidas, significando elevado grau de complexidade tanto na logística de aplicação da pesquisa quanto em especial na elaboração dos planos de ações de melhoria do clima organizacional nos diversos níveis da organização.

\begin{tabular}{|c|c|c|c|c|}
\hline $1^{\text {a }}$ ETAPA & $2^{a}$ ETAPA & $\mathbf{3}^{\mathbf{a}}$ ETAPA & $4^{a}$ ETAPA & 5 $^{\mathbf{a}}$ ETAPA \\
\hline $\begin{array}{l}\text { Planejamento e } \\
\text { realização da } \\
\text { Pesquisa em âmbito } \\
\text { nacional }\end{array}$ & $\begin{array}{l}\text { Análise dos } \\
\text { Dados e } \\
\text { Divulgação dos } \\
\text { Resultados }\end{array}$ & $\begin{array}{l}\text { Elaboração dos Planos } \\
\text { de Ação de Melhoria } \\
\text { Corporativo, Regionais } \\
\text { e das unidades }\end{array}$ & $\begin{array}{l}\text { Implantação } \\
\text { das Ações de } \\
\text { Melhoria }\end{array}$ & $\begin{array}{l}\text { Avaliação do } \\
\text { ciclo }\end{array}$ \\
\hline
\end{tabular}

Quadro 6 - As 5 macro-etapas do ciclo de gestão do clima organizacional na ECT.

Fonte: Manual interno da ECT. 
Para que os empregados percebam efetivamente as melhorias implantadas pela empresa em decorrência dos resultados das pesquisas de clima organizacional, é necessário que haja um lapso de tempo adequado para tanto.

A Pesquisa de Clima Organizacional realizada na ECT configura-se como de natureza quantitativa, de corte transversal, uma vez que avalia o contexto organizacional percebido pelo empregado no momento da sua realização. A coleta de dados se dá por meio de um questionário padronizado. O questionário utilizado para coleta de dados é especialmente construído para cada pesquisa. Contém as orientações necessárias ao seu preenchimento e devolução. Inclui itens com afirmativas sobre os diversos aspectos relacionados com o contexto do trabalho. Os itens são apresentados aos respondentes em uma escala de 5 pontos, do tipo Likert, conforme especificado a seguir: 1- discordo totalmente; 2 - discordo na maior parte; 3 - às vezes concordo, às vezes discordo; 4 - concordo na maior parte; 5 - concordo totalmente.

A pesquisa é de caráter censitário, abrangendo todos os empregados ativos e em efetivo exercício na ECT em cada uma de suas unidades. Para participar da pesquisa o empregado deve contar com pelo menos 3 (três) meses de trabalho e não estar requisitado para outro órgão da administração pública, afastado por licença médica com prazo superior a 15 dias ou afastado por licença particular. O nível de participação dos profissionais vem aumentando gradativamente como demonstram os dados dos ciclos de: 2004 - 67,4\%; 2005 - 68,4\%; 2007 - 75,4\%, diminuindo em 2008 - 66,2\%, valores representados na série histórica do Gráfico 1.

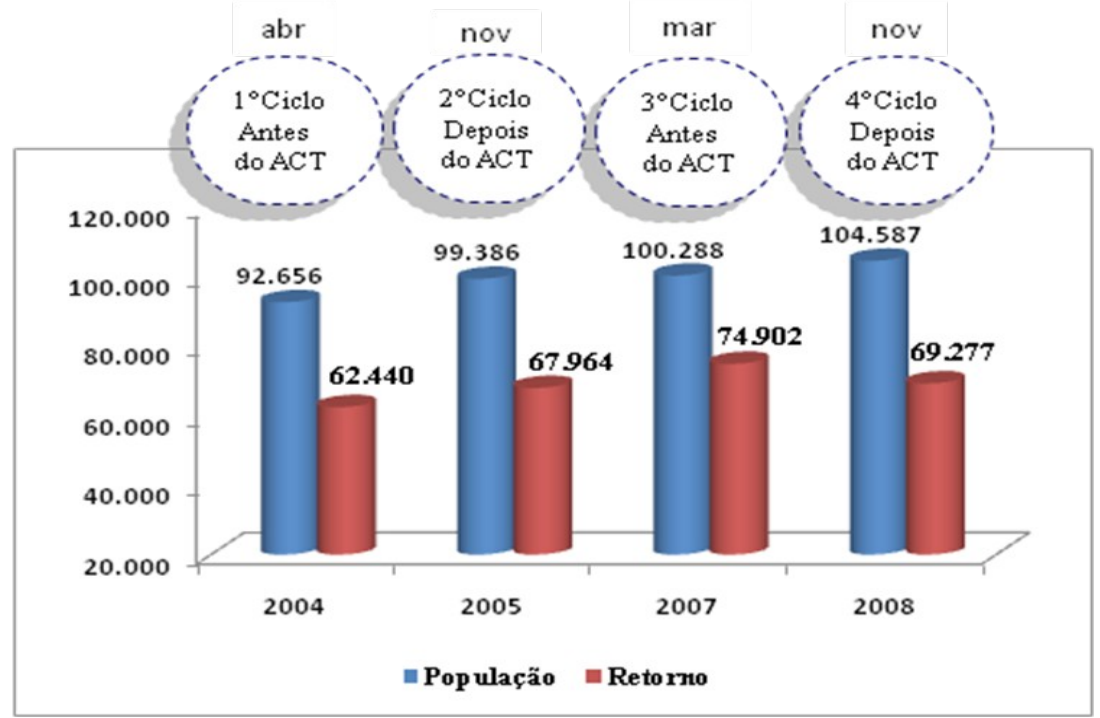

Gráfico 1 - Série histórica dos ciclos das pesquisas de clima.

Fonte: Dados das pesquisas de clima dos anos de 2004, 2005, 2007 e 2008. 
O prazo para coleta de dados é de 14 dias (duas semanas), a partir da data de início da aplicação dos questionários. Os dados são tratados em softwares específicos de análise estatística de pesquisas sociais. Definida a quantidade de questionários válidos, os dados da pesquisa são objeto de análises estatísticas descritivas e inferenciais. Adota-se como procedimento básico a análise fatorial do questionário, de modo a identificar os fatores que agrupam os itens pesquisados.

O agrupamento apurado pela análise fatorial reproduz a forma como os empregados percebem a inter-relação entre os itens da pesquisa, ou seja: os itens se relacionam entre si porque têm uma causa comum que produz essa aproximação, na visão dos participantes da pesquisa.

Dessa forma, chegou-se a 11 fatores, apresentados no Quadro 7, que contém a dimensão conceitual de cada um deles.

\begin{tabular}{|c|c|}
\hline NOMEDO FATOR & CONCEITO \\
\hline $\begin{array}{l}\text { Ambiente Físico e Condições } \\
\text { de Trabalho }\end{array}$ & $\begin{array}{l}\text { Percepção do empregado sobre as suas condições de trabalho, em relação aos móveis e } \\
\text { equipamentos, disponibilidade de recursos materiais, segurança física e condições gerais do } \\
\text { ambiente físico - espaço, iluminação e ventilação. }\end{array}$ \\
\hline Atuação da Chefia & $\begin{array}{l}\text { Percepção e avaliação do empregado sobre a sua chefia, no tocante à gestão da equipe e dos } \\
\text { processos de trabalho, à comunicação sobre a Empresa, ao relacionamento com o colaborador, } \\
\text { à abertura a críticas, estímulo ao autodesenvolvimento do colaborador, competência } \\
\text { profissional e confiança do colaborador. }\end{array}$ \\
\hline Benefícios & $\begin{array}{l}\text { Avaliação do empregado sobre a assistência médico-odontológica e demais benefícios } \\
\text { oferecidos pela Empresa. }\end{array}$ \\
\hline Comunicação & $\begin{array}{l}\text { Avaliação do empregado sobre a rapidez e eficácia dos meios de comunicação e sua influência } \\
\text { no relacionamento da Empres a com o empregado. }\end{array}$ \\
\hline $\begin{array}{l}\text { Educação e Crescimento } \\
\text { Profissional }\end{array}$ & $\begin{array}{l}\text { Percepção do empregado sobre as oportunidades de treinamento e crescimento profissional } \\
\text { oferecidas pela Empresa, e sobre a contribuição do treinamento para o desempenho. }\end{array}$ \\
\hline Equipe de Trabalho & $\begin{array}{l}\text { Percepção e avaliação do empregado sobre a equipe de trabalho, no tocante ao } \\
\text { compartilhamento de informações, integração, relacionamento, confiança entre os membros, } \\
\text { integração pessoal, respeito e comprometimento com resultados. }\end{array}$ \\
\hline Imagem Institucional & $\begin{array}{l}\text { Percepção e avaliação do empregado sobre a imagem e credibilidade da empresa junto a } \\
\text { clientes, familiares, comunidade e pessoas do seu relacionamento, e sua visão da ECT como } \\
\text { um bom local para trabalhar. }\end{array}$ \\
\hline $\begin{array}{l}\text { Integração Empregado- } \\
\text { Empresa }\end{array}$ & $\begin{array}{l}\text { Percepção e avaliação do empregado sobre a atuação do Serviço Social e a oferta de atividades } \\
\text { de lazer, esporte e cultura, e ainda o grau de contribuição dos eventos para a melhoria do clima, } \\
\text { qualidade de vida e aproximação do empregado com a Empresa. }\end{array}$ \\
\hline Natureza do Trabalho & $\begin{array}{l}\text { Percepção e avaliação do empregado acerca da motivação, satis fação e realização pessoal com } \\
\text { o trabalho, além da maneira como o mesmo concilia a sua vida pessoal com a carga de trabalho } \\
\text { na Empresa. }\end{array}$ \\
\hline Relacionamento entre Áreas & $\begin{array}{l}\text { Avaliação do empregado sobre o relacionamento, colaboração e cooperação entre as áreas da } \\
\text { Empresa, além da integração entre elas visando ao atingimento dos objetivos organizacionais. }\end{array}$ \\
\hline Remuneração & $\begin{array}{l}\text { Percepção e avaliação do empregado sobre a sua remuneração e sobre a compatibilidade entre } \\
\text { o que se pratica na Empresa e no mercado. }\end{array}$ \\
\hline
\end{tabular}

Quadro 7 - Fatores e conceitos da pesquisa de clima organizacional da ECT.

Fonte: Manual interno da ECT. 
Para cada item do questionário são apresentados os percentuais de discordância, neutralidade e concordância e o respectivo índice de favorabilidade, que consiste na transformação em percentual da média das respostas a todas as alternativas do item. A ECT, a Administração Central (corresponde à matriz da Empresa) e cada Diretoria Regional (corresponde às filiais) têm suas metas específicas.

Conforme as políticas de gestão do clima organizacional na ECT, a aplicação de pesquisas de clima deve estar atrelada a compromissos de efetiva implantação de ações que objetivem melhorar a percepção do empregado em relação ao trabalho na Empresa.

Levando em conta o Critério de Interpretação e Análise dos resultados das Pesquisas de Clima Organizacional, descrito na Tabela 1 a seguir, os resultados considerados desfavoráveis serão o insumo fundamental para a elaboração dos Planos de Ações de Melhoria do Clima Organizacional na ECT.

Tabela 1- Critério de Interpretação e Análise dos resultados das Pesquisas de Clima Organizacional

\begin{tabular}{|l|c|}
\hline \multicolumn{1}{|c|}{ Critério de Interpretação } & Índice de Favorabilidade \\
\hline Resultado Favorável & Acima de $80 \%$ \\
\hline Resultado Satisfatório - faixa (+) & Entre $75 \%$ e $80 \%$ \\
\hline Resultado Satisfatório - faixa (-) & Entre $70 \%$ e $75 \%$ \\
\hline Resultado Desfavorável & Abaixo de $70 \%$ \\
\hline
\end{tabular}

Fonte: Manual interno da ECT.

No Apêndice B são apresentados de forma sintética os índices de favorabilidade aferidos nas pesquisas de clima organizacional de 2005, 2007 e 2008: geral e por fator dos $70 \mathrm{CEE}$ analisados neste estudo, dispostos por grupo (1, 2, 3, 4 e 5), DR e individualizados por unidade.

A evolução das quantidades de unidades em cada grupo que obtiveram resultados dos índices de favorabilidade igual ou maior que a meta pode ser acompanhada nos gráficos a seguir. A medida retratada são os resultados gerais (CEE) e dos fatores avaliados pelos empregados sobre os diversos aspectos relacionados ao contexto organizacional. Vale destacar que a meta definida para o indicador clima organizacional de cada centro de entrega de encomendas é fixada tendo como referência o resultado da pesquisa na DR como um todo. 

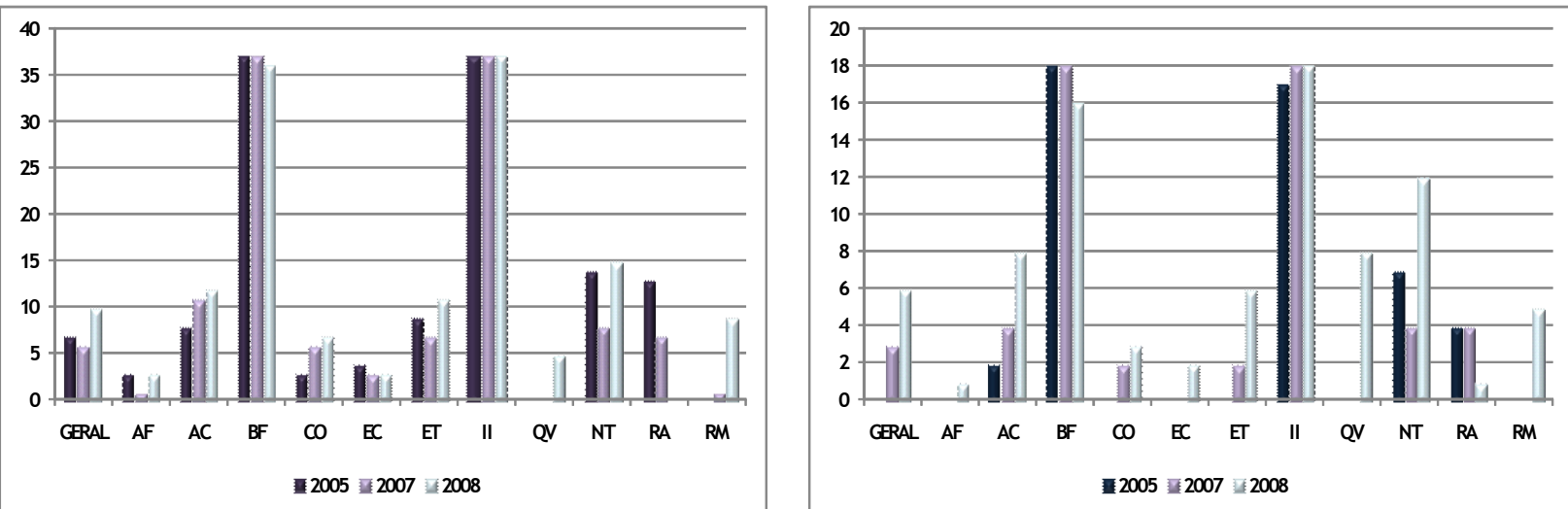

Gráfico 2 - Evolução das quantidades de CEE do grupo 1, Gráfico 3 - Evolução das quantidades de CEE do grupo de 37 unidades, com resultados da pesquisa de clima igual 2, de 18 unidades, com resultados da pesquisa de clima ou acima da meta. igual ou acima da meta.
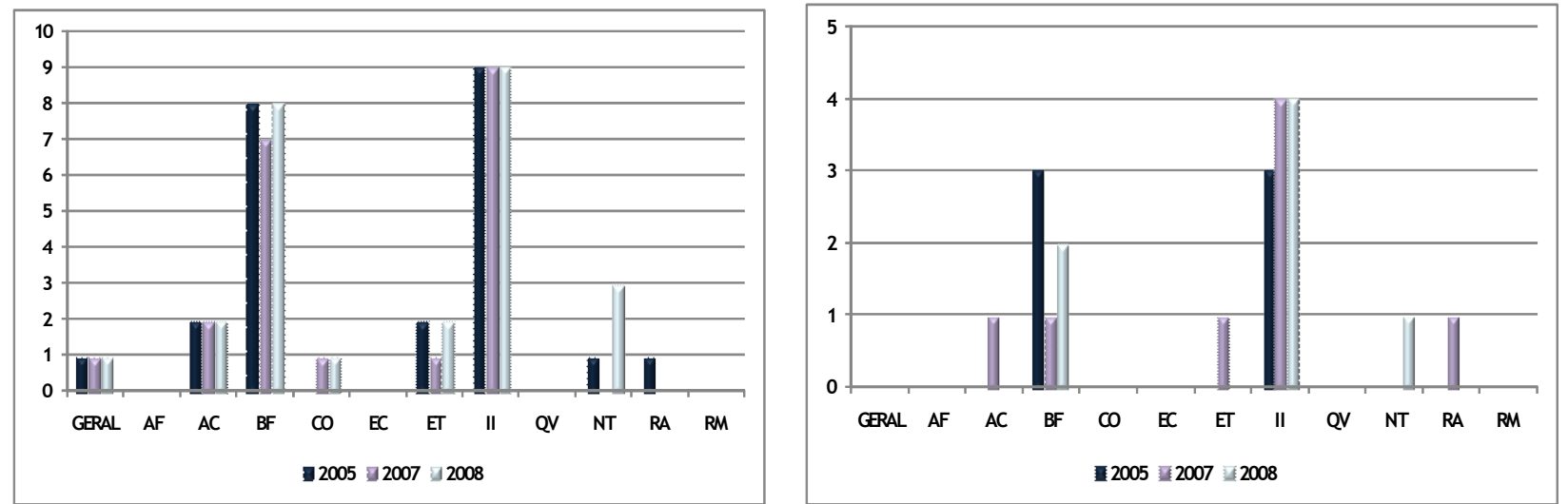

Gráfico 4 - Evolução das quantidades de CEE do grupo 3 , de 9 unidades, com resultados da pesquisa de clima igual ou acima da meta.

Gráfico 5 - Evolução das quantidades de CEE do grupo 4 , de 4 unidades, com resultados da pesquisa de clima igual ou acima da meta.

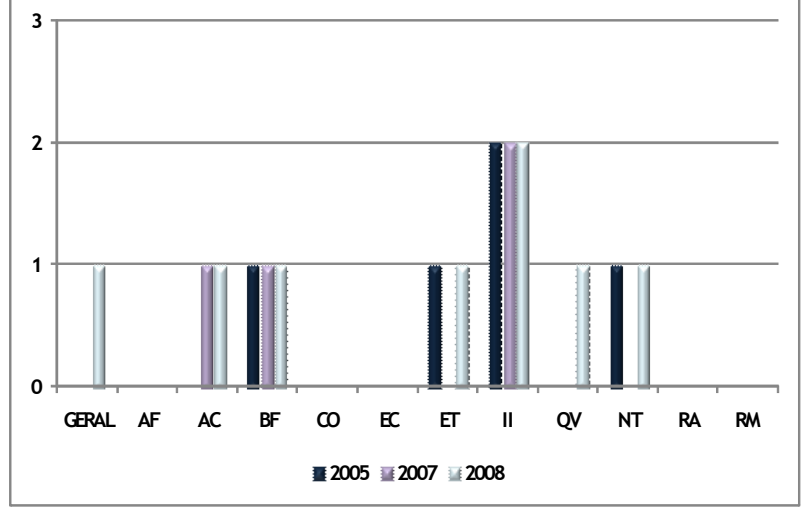

Gráfico 6 - Evolução das quantidades de CEE do grupo 5 , de 2 unidades, com resultados da pesquisa de clima igual ou acima da meta. 
Ao se observar os resultados gerais (GERAL) de todos os grupos de CEE, pode-se notar que as quantidades de unidades com índices de favorabilidade igual ou acima da meta são inexpressíveis nos três anos avaliados, ou seja, os resultados mostram que existe uma discordância da percepção do empregado ao ambiente organizacional oferecido pela empresa. Porém, percebe-se uma melhora na visão dos empregados a partir da pesquisa de 2008, com exceção do grupo 4 (Gráfico 5).

Os fatores como benefícios (BE) e imagem institucional (II) apresentam resultados que refletem, predominantemente, uma boa percepção dos empregados de todos os grupos. No entanto, percebe-se um declínio, pequeno, no fator benefício em 2008. Nesse mesmo ano nota-se, a evolução nos demais fatores como: ambiente físico e condições de trabalho (AF), atuação da chefia (AC), equipe de trabalho (ET), imagem institucional (II) e natureza do trabalho (NT).

Os resultados dos fatores: relacionamento entre as áreas (RA), remuneração (RM), comunicação $(\mathrm{CO})$ e educação e desenvolvimento (EC) não correspondem a mesma evolução.

Apresentados os resultados relativos ao indicador de clima organizacional, o tópico a seguir tratará da apresentação do indicador qualidade operacional.

\subsection{Qualidade Operacional}

O indicador Qualidade Operacional refere-se ao desempenho da distribuição dos serviços postais (tais como cartas, malotes, impressos, encomendas SEDEX, PAC (serviço de remessa econômica de mercadorias com entrega domiciliar), etc.) dentro do prazo, entregues à sociedade pelas unidades dos Correios.

O serviço SEDEX distribuídos pelos CEE faz parte da cesta de indicadores de desempenho operacional (IDO) da Área de Encomendas, sendo uma das parcelas do Índice de Qualidade Operacional (IQO) que compõe o conjunto dos 8 (oito) indicadores estratégicos da ECT, vinculados à perspectiva Processos Internos.

A apuração do IDO é automática, desde 2005, sendo disponibilizada a todos os gestores operacionais das 28 Diretorias Regionais (DR) da ECT por meio da ferramenta denominada Data Warehouse $(D W)$, que oferece informações essenciais para a gestão e tomada de decisão, sendo possível analisar os resultados por dia da semana, por região geográfica e, principalmente, pelas unidades operacionais, individualmente. 
No Apêndice C são apresentados de forma sintética os resultados dos indicadores de desempenho operacional (IDO) do serviço SEDEX dos 70 CEE analisados neste estudo, dispostos por grupo (1, 2, 3, 4 e 5), DR e individualizados por unidade.

A evolução das quantidades e percentual de unidades em cada grupo que obtiveram resultado do IDO abaixo da meta pode ser acompanhada na tabela a seguir. Vale destacar que a meta para o indicador do IDO é individualizada por centro de entrega de encomendas. A meta em 2005 é comum para todas as unidades, sendo alterada em 2007 e 2008 tendo como referência os resultados alcançados. Como a negociação coletiva acontece em meados de julho até agosto de cada ano, foram levantados os resultados do SEDEX dos meses de julho, agosto, setembro e outubro a fim de observarmos o cenário do processo produtivo das unidades, durante e após as negociações nos anos de 2005, 2007 e 2008.

Tabela 2 - Quantidade e percentual de CEE que obtiveram resultado do IDO do serviço SEDEX abaixo da meta.

\begin{tabular}{|c|c|c|c|c|c|c|c|}
\hline \multirow{2}{*}{ ANO } & \multirow{2}{*}{ MÊS } & \multicolumn{2}{|c|}{ GRUPO 1} & \multicolumn{2}{|c|}{ GRUPO 2} & \multicolumn{2}{|c|}{ GRUPO 3} \\
\hline & & Quantidade & Percentual & Quantidade & Percentual & Quantidade & Percentual \\
\hline \multirow{4}{*}{2005} & JUL & 37 & $100 \%$ & 18 & $100 \%$ & 9 & $100 \%$ \\
\hline & AGO & 37 & $100 \%$ & 18 & $100 \%$ & $\overline{9}$ & $100 \%$ \\
\hline & SET & 37 & $100 \%$ & 18 & $100 \%$ & $\overline{9}$ & $100 \%$ \\
\hline & OUT & 37 & $100 \%$ & 18 & $100 \%$ & $\overline{9}$ & $100 \%$ \\
\hline \multirow{4}{*}{2007} & JUL & 6 & $16 \%$ & 15 & $83 \%$ & $\overline{9}$ & $100 \%$ \\
\hline & AGO & 1 & $3 \%$ & $\overline{9}$ & $50 \%$ & $\overline{6}$ & $67 \%$ \\
\hline & SET & 28 & $76 \%$ & 15 & $83 \%$ & 8 & $89 \%$ \\
\hline & OUT & 9 & $24 \%$ & 3 & $17 \%$ & $\overline{6}$ & $67 \%$ \\
\hline \multirow{4}{*}{2008} & JUL & 33 & $89 \%$ & 16 & $89 \%$ & $\overline{9}$ & $100 \%$ \\
\hline & $\overline{A G O}$ & 28 & 76\% & 16 & $89 \%$ & $\overline{9}$ & $100 \%$ \\
\hline & SET & 34 & $92 \%$ & 15 & $83 \%$ & $\overline{9}$ & $100 \%$ \\
\hline & OUT & 20 & $54 \%$ & 14 & $78 \%$ & 9 & $100 \%$ \\
\hline \multirow{2}{*}{ ANO } & \multirow{2}{*}{ MÊS } & \multicolumn{2}{|c|}{ GRUPO 4} & \multicolumn{2}{|c|}{ GRUPO 5} & & \\
\hline & & Quantidade & Percentual & Quantidade & Percentual & & \\
\hline \multirow{4}{*}{2005} & JUL & 4 & $100 \%$ & 2 & $100 \%$ & & \\
\hline & AGO & 4 & $100 \%$ & 2 & $100 \%$ & & \\
\hline & SET & 4 & $100 \%$ & 2 & $100 \%$ & & \\
\hline & OUT & 4 & $100 \%$ & 2 & $100 \%$ & & \\
\hline \multirow{4}{*}{2007} & JUL & 4 & $100 \%$ & 2 & $100 \%$ & & \\
\hline & AGO & 4 & $100 \%$ & 1 & $50 \%$ & & \\
\hline & SET & 4 & $100 \%$ & 2 & $100 \%$ & & \\
\hline & OUT & 3 & $75 \%$ & 2 & $100 \%$ & & \\
\hline \multirow{4}{*}{2008} & JUL & 4 & $100 \%$ & 2 & $100 \%$ & & \\
\hline & AGO & 4 & $100 \%$ & $\overline{2}$ & $100 \%$ & & \\
\hline & SET & 4 & $100 \%$ & 2 & $100 \%$ & & \\
\hline & OUT & 4 & $100 \%$ & 2 & $100 \%$ & & \\
\hline
\end{tabular}


No ano de 2005 todas as unidades tiveram desempenho abaixo da meta. Este período corresponde à fase de transição da apuração desse indicador, de manual para automática. Em 2004 os resultados extraídos, manualmente, do desempenho da distribuição do SEDEX de todas as DR, giravam em torno de $99 \%$. Com a aferição automática o resultado passou a ser menor, conforme levantamento.

Em torno de $80 \%$ do serviço SEDEX dos Correios são distribuídos pelas unidades do grupo 1 (ES, MG, RJ, SPI e SPM) e grupo 2 (BSB, GO, MS, PR, RS e SC). O ano de 2007 as unidades apresentaram um melhor desempenho em relação aos outros períodos. Em 2008 o desempenho das unidades volta a ser abaixo da meta, recuperando-se em outubro, sobretudo em relação às unidades dos grupos 1 e 2 .

No tópico seguinte serão apresentadas as discussões de resultado deste trabalho. 


\section{DISCUSSÃO DOS RESULTADOS}

Inicialmente, identifica-se que o processo de negociação coletiva nos Correios encontra-se bem estruturado, percebendo-se uma evolução com o passar dos anos. É evidente a existência de dois momentos: o primeiro caracterizado pela inexperiência, o que acarretava conseqüências para organização, tais como o desgaste nas negociações, e o atual, que inclui os períodos de 2002, 2004, 2006 e 2008 propostos para análise neste trabalho, que demonstram uma busca pela profissionalização no tratamento das questões sindicais. Parte destas mudanças são reflexos das mudanças, pequenas, mais que tiveram influências nas relações de trabalho, introduzidas com a $\mathrm{CF} / 88$.

No que concerne à decisão da empresa em investir no quadro de pessoal, são observados os ajustes ocorridos na própria estrutura da ECT. Porém, em 2008, mesmo com a criação do Comitê Permanente de Relações do Trabalho (CPRT), infere-se que houve uma perda para o processo de negociação. Uma equipe restrita, contanto com sete pessoas, tem dificultada a tarefa de acompanhar e atuar de forma mais intensiva com as ASGET regionais, bem como desenvolver outras ações de gestão das relações sociais de trabalho e sindical.

O reflexo foi a decretação de 3 greves ao longo de 2008. Em consequencia, observa-se que as unidades não apresentaram um bom resultado, tendo um alto índice de CEE com resultados abaixo da meta. Isso se repete em quase todos os grupos e meses analisados. As unidades começam a ter um resultado satisfatório a partir de outubro/2008. Este é um ano, também, considerado pelo CPRT como crítico para empresa durante as fases de negociação e de atuação do próprio comitê junto as DR, pela sua limitação de pessoal.

Em virtude da imparcialidade das apurações do serviço SEDEX. Em relação ao IDO em 2005, houve uma conscientização em torno da máxima: "melhor um resultado ruim e real do que um ótimo e irreal". Percebe-se uma melhoria na qualidade do desempenho do serviço SEDEX no ano de 2007, com uma maior concentração dos resultados acima da meta nos meses de agosto e outubro, de início e após o processo de negociação coletiva. Infere que em setembro ao longo dos anos de 2007 e 2008, períodos de transição da assinatura dos acordos coletivos, quase na totalidade dos $70 \mathrm{CEE}$, aderiram às mobilizações sindicais em todo territorial nacional, obtendo resultados de desempenho do serviço SEDEX abaixo da meta. 
A melhoria no resultado desse indicador também é consequência de inúmeras ações de gestão. Com a automação das informações do IDO do serviço SEDEX, há uma facilidade no controle e no acompanhamento tanto dos empregados no exercício de suas atividades quanto na atuação dos gestores. O que também pode ser reflexo dos treinamentos e da atuação da chefia. É difícil determinar o impacto das negociações no desempenho, uma vez que o resultado é consequência de uma série de esforços.

Outro indicador que tem uma relação direta com o processo de negociação coletiva é o clima organizacional. Aplicado em 2005 (novembro), 2007 (março) e 2008 (novembro) os resultados mostram uma evolução dos índices de favorabilidade segundo a percepção dos empregados, o que pode ser consequência de ações de melhoraria do ambiente organizacional e das relações de trabalho pela organização, a exemplo do ambiente físico e condições de trabalho pela disponibilização de móveis e equipamentos ergonômicos que trazem segurança e propiciam a qualidade de vida aos empregados o que reflete na sua natureza do trabalho com a diminuição da carga de trabalho, o que torna o empregado satisfeito e motivado.

Os fatores como benefícios e remuneração, por terem impacto financeiro para organização, exigem uma parcela maior de tempo nas tratativas da negociação coletiva. Porém observa-se uma relação inversa da evolução das alterações dos acordos coletivos com os resultados obtidos nas pesquisas.

Nota-se uma tendência relativamente duradoura do fator benefício percebido e interpretado pelo empregado. Ao contrário do fator remuneração que mesmo com alterações em todos os processos de negociação, não tem a mesma percepção e interpretação, podendo ter influências de ajustes anteriores à negociação como ocorreu em 2008, com a concessão de 30\% de acréscimo ao salário dos empregados que realizam as atividades de distribuição domiciliária, o que deduz influenciou na melhora nos resultados da pesquisa de 2008.

Olhando a evolução das cláusulas dos ACT, dos resultados do clima organizacional e do IDO podem ser explicados pelo investimento da Empresa na qualidade dos processos, ferramentas de acompanhamento e de gestão, tanto da negociação coletiva quanto dos indicadores analisados, que subsidiam as ações implantadas pelos Correios na melhoria do ambiente organizacional com a percepção do empregado. 


\section{CONCLUSÃO}

O trabalho foi desenvolvido com o propósito de analisar a evolução dos acordos coletivos de 2002/2003, 2004/2005, 2006/2007 e 2008/2009 da ECT, e a influência desses acordos no resultado dos indicadores de gestão organizacional: clima organizacional e desempenho operacional. Ao longo deste trabalho houve as explicações das fases da negociação coletiva e as ações adotadas pela empresa. A partir daí procurou-se analisar os resultados dos indicadores.

Com os dados obtidos pôde-se concluir que a empresa tem atuado de forma profissional, percebendo uma evolução nas tratativas do processo de negociação, com a interação com os órgãos sindicais, não somente durante as negociações coletivas, mas ao longo do ano, de modo a ter um mapeamento dos anseios e interesses dos empregados.

Neste estudo, foi possível concluir que ambos os indicadores - clima organizacional e desempenho operacional - são influenciados pelas negociações. Percebe-se uma melhoria na visão dos empregados dos fatores avaliados na pesquisa de clima organizacional, comparando os períodos de 2005, 2007 e 2008, o que infere que esse resultado tanto pode refletir o amadurecimento das relações quanto ao conjunto de ações de melhorias previstas no processo de gestão do clima organizacional.

Com relação ao monitoramento do indicador de desempenho operacional observa-se que durante e após o processo de negociação existe um reflexo nos resultados, onde as unidades começam a ter um resultado satisfatório no desempenho da distribuição do serviço SEDEX a partir de outubro nos anos de 2007 e 2008.

A evolução das políticas dos ACT é verificada com os resultados das pesquisas de clima organizacional que servem de insumo para a elaboração dos planos de ação implantados pela organização.

Finalmente, reforça a necessidade de a empresa se preparar para o processo de negociação coletiva, avaliando e acompanhando o panorama organizacional por meios dos seus indicadores. Tal fato, contudo, traz consigo desafios, pois a empresa precisa conciliar os interesses dos empregados, ora representado pelos sindicatos, à sustentabilidade da organização. 


\section{REFERÊNCIAS BIBLIOGRÁFICAS}

BRASIL, Decreto n ${ }^{\circ}$ 908, de 31 de agosto de 1993.

. Constituição (1988). Emenda constitucional nº . 48, de setembro de 2005, 37.ed.rev.e aum. - São Paulo: Saraiva , 2005.

CAVAlCANTI, Melissa Franchini. Dos Aspectos da Negociação nos Contratos Interncionais: análise service level agreement. In: Jete Jane Fiorati; Valério de Oliveira Mazzuoli. (Org.). Novas Vertentes do Direito do Comércio Internacional. $1^{\text {a }}$ ed. São Paulo - SP: Manole, v. 1, p. 105-129, 2003.

FISHER, R; URY, W; PATTON, B. Como chegar ao sim: negociação de acordos sem concessões. Tradução: Vera Ribeiro \& Ana Luiza Borges - $2^{\mathrm{a}}$ ed.rev.e aum. - Rio de Janeiro: Imago Ed.; 1994.

FNQ - FUNDAÇÃO NACIONAL DA QUALIDADE. Cadernos de excelência: Resultados / Fundação Nacional da Qualidade. - São Paulo: Fundação Nacional da Qualidade, 2008. - (Série Cadernos de Excelência, n.8).

GERNIGON, B; ODERO, A; GUIDO, H et al. A negociação coletiva na administração pública brasileira. - Brasília: OIT; Rio de Janeiro: Forense, 2002.

HERNANDEZ, J. A. E; MELO, F. M. O clima organizacional e a satisfação dos funcionários de um Centro Médico Integrado. Revista Psicologia: Organizações e Trabalho, v. 3, n.1, p. 11-26, 2003.

JUNQUEIRA, LUIS AUGUSTO COSTACURTA. Negociação: tecnologia de comportamento. São Paulo: Cop Edit, Rio de Jneiro, 1998.

KAPLAN, ROBERT S; NORTON, DAVID P. A estratégia em ação: balanced scorecard; tradução Luiz Euclydes Trindade Frazão Filho. - Rio de Janeiro: Elesevier, 1997 - 23 ${ }^{\mathrm{a}}$ Reimpressão.

LEWICKI, R; HIAM, A. MBA compacto, estratégias de negociação e fechamento. Tradução: de Isabel de Paula e Silva Corrêa. - Rio de Janeiro: Campos, 2003.

MARANHÃO, M. O processo nosso de cada dia: modelagem de processos de trabalho/Mauriti Maranhão, Maria Elisa Bastos Macieira. - Rio de Janeiro: Qualitymark Editora, 2004. 
MARTINELLI, D.P. Negociação, administração e sistemas: três níveis a serem interrelacionados. Revista de Administração, v. 41, n. 4, p. 353-368, out/nov/dez. 2006.

MELO, M. C. O. L. Negociação coletiva: Tratamento Teórico e prática. Revista de Administração de Empresas. São Paulo, 31 (4): 49-62. Out/dez, 1991.

OIT - Organização Internacional do Traballho. Disponível em : <http://www.oitbrasil.org.br/>. Acesso em: 08 mai. 2009.

PACE, E. S. U.; BASSO; L. F. C.; SILVA, M. A. Indicadores de Desempenho como Direcionadores de Valor. RAC, v. 7, n. 1, jan./mar. 2003: 37-65.

PINHEIRO, I. A. Fatores do clima organizacional que são motivadores para a Inovação tecnológica em um centro de tecnologia. REAd - Edição 29, v. 8, n.5, set/out. 2002.

POPADIUK, S; PEREIRA, L. F. P.; FRANKLIN, M. A. et al. Arquitetura da informação e mensuração do desempenho: um estudo na indústria de artefatos e utensílios de plásticos no Estado de São Paulo. Gest. Prod., v.13, n.1, p.151-165, jan./abr. 2006.

ROBBINS, STEPHEN P. Comportamento organizacional; tradução técnica Reynaldo Marcondes. - 11. ed. - São Paulo: Person Prentice Hall, 2005.

SIQUEIRA, JOSÉ FRANCISCO NETO. Direito do trabalho e negociação coletiva. Organização de Cláudio Salvatori Dedecca. - São Paulo: Associação Brasileira de Estudos do Trabalho ABET, 1998. (Coleção ABET - Mercado de Trabalho, v.8).

WENDLAND, D. Contratos coletivos e depoimentos orais: um cruzamento de fatores na história da Intercel, 1964-2004. Universidade Federal de Santa Catarina, 2006. Disponível em: $<$ www.cfh.ufsc.br/abho4sul/pdf/Daniely\%20Wendland.pdf>. Acesso em: 13 nov. 2008.

YIN, R. K. Estudo de caso: planejamento e métodos/Robert K. Yin; Tradução: Daniel Grassi. - 3. ed. - Porto Alegre: Brookman, 2005. 
APÊNDICE 


\section{APÊNDICE A}

\begin{tabular}{|c|c|c|c|c|c|}
\hline \multicolumn{6}{|c|}{ Comparativo das cláusulas dos acordos coletivos de trabalho (ACT) de 2002/2003 a 2008/2009 } \\
\hline Blocos & Cláusulas & \begin{tabular}{|c|} 
ACT \\
2002/2003
\end{tabular} & \begin{tabular}{|c|} 
ACT \\
2004/2005
\end{tabular} & \begin{tabular}{|c|} 
ACT \\
2006/2007
\end{tabular} & \begin{tabular}{|c|} 
ACT \\
$2008 / 2009$
\end{tabular} \\
\hline \multirow{6}{*}{ BENEFICIO } & Assistência médica/hospitalar e odontológica & & Alterou & \begin{tabular}{|l|l} 
Alterou \\
\end{tabular} & Alterou \\
\hline & Auxilio p/ filhos dependentes de cuidados especiais & & Alterou & Alterou & Alterou \\
\hline & Reembolso-Creche & & Alterou & Alterou & Alterou \\
\hline & Saúde do empregado & & Alterou & Alterou & Alterou \\
\hline & Vale-refeição/Alimentação & & Alterou & Alterou & Alterou \\
\hline & \begin{tabular}{|l} 
Vale transporte e jornada de trabalho "IN ITINERI" \\
\end{tabular} & Ausente & Icluiu & Manteve & Alterou \\
\hline \multirow{11}{*}{ ECONÔMICO } & Acumulação de vantagens & & Manteve & Manteve & Manteve \\
\hline & \begin{tabular}{|l|} 
Adiantamento de férias \\
\end{tabular} & & Manteve & Alterou & Alterou \\
\hline & \begin{tabular}{|l|l} 
Adicional noturno \\
\end{tabular} & & Manteve & Alterou & Manteve \\
\hline & \begin{tabular}{|l|} 
Ajuda de custo na transferência \\
\end{tabular} & & Manteve & Alterou & Manteve \\
\hline & \begin{tabular}{|l|l} 
Antecipação de $50 \%$ da gratificação natalina \\
\end{tabular} & & Alterou & Manteve & Manteve \\
\hline & Anuênio/quinquênios & & Manteve & Alterou & Manteve \\
\hline & \begin{tabular}{|l|} 
Gratificação de férias \\
\end{tabular} & & Manteve & Manteve & Manteve \\
\hline & Gratificação de quebra de caixa & & Alterou & Alterou & Alterou \\
\hline & Pagamento de salário & & Manteve & Manteve & Manteve \\
\hline & Participação dos empregados nas discussões da PLR - Participação nos lucros e resultados & Ausente & Manteve & Manteve & Manteve \\
\hline & Reajuste Salarial & & Alterou & Alterou & Alterou \\
\hline \multirow{16}{*}{ SOCIAL } & Acompanhante & & $\overline{\text { Alterou }}$ & Alterou & Manteve \\
\hline & \begin{tabular}{|l|} 
Anistia \\
\end{tabular} & Ausente & Icluiu & Manteve & Manteve \\
\hline & \begin{tabular}{|l} 
Assédio Sexual e Assédio Moral \\
\end{tabular} & Ausente & Icluiu & Manteve & Manteve \\
\hline & \begin{tabular}{|l|} 
Concurso Público \\
\end{tabular} & Ausente & Icluiu & Manteve & Manteve \\
\hline & Desconto assintencial & & Manteve & Manteve & Manteve \\
\hline & Direito à ampla defesa & Ausente & Icluiu & Manteve & Manteve \\
\hline & Discriminação e preconceitos & & Excluiu & Ausente & Ausente \\
\hline & \begin{tabular}{|l|} 
Discriminação racial \\
\end{tabular} & Ausente & Icluiu & Manteve & Manteve \\
\hline & Empregado portador do vírus HIV & & Alterou & Manteve & Manteve \\
\hline & \begin{tabular}{|l|} 
Garatias à mulher ecetista \\
\end{tabular} & & Alterou & Alterou & Alterou \\
\hline & Garantias ao Empregado Estudante & & Alterou & Manteve & Manteve \\
\hline & Licença adoção & Ausente & Icluiu & Alterou & Alterou \\
\hline & Processo Licitatório (indicação de empregado para observação das reuniões) & & Excluiu & Ausente & Ausente \\
\hline & Período de amamentação & & & Alterou & Manteve \\
\hline & Programa casa própria & Ausente & Icluiu & Manteve & Manteve \\
\hline & Prorrogação da licença-maternidade & Ausente & Ausente & Ausente & Inclui \\
\hline \multirow{34}{*}{ TRABALHO } & Acesso às dependências & & Alterou & Alterou & Alterou \\
\hline & Atestado de saúde na demissão & Ausente & Manteve & Manteve & Manteve \\
\hline & Conciliação de divergências & & Manteve & Manteve & Manteve \\
\hline & Contratação de Empregados & Ausente & Icluiu & Manteve & Manteve \\
\hline & Cursos e reuniões obrigatórios & & Manteve & Manteve & Manteve \\
\hline & Delegado Sindical & Ausente & Icluiu & Manteve & Manteve \\
\hline & \begin{tabular}{|l|l} 
Distribuição Domiciliária \\
\end{tabular} & & Alterou & Manteve & Manteve \\
\hline & Fornecedor de CAT/LISA & & Manteve & Manteve & Manteve \\
\hline & Fornecimento de documentos básicos & & Manteve & Manteve & Manteve \\
\hline & Horas-Extras & & Manteve & Manteve & Manteve \\
\hline & \begin{tabular}{|l|l} 
Inovações Tecnológicas \\
\end{tabular} & & Manteve & Manteve & Manteve \\
\hline & Itens de uso e proteção ao empregado & & Alterou & Manteve & Manteve \\
\hline & Jornada de trabalho nas Agências de Correio & Ausente & Icluiu & Manteve & Manteve \\
\hline & Jornada de trabalho para trabalhadores em terminais computadorizados & Ausente & Icluiu & Manteve & Manteve \\
\hline & Liberação de dirigentes sindicais & & Manteve & Manteve & Alterou \\
\hline & Comissão interna de prevenção de acidentes - CIPA & Ausente & Icluiu & Manteve & Manteve \\
\hline & \begin{tabular}{|l|l} 
Medidas de segurança \\
\end{tabular} & Ausente & Icluiu & Manteve & Manteve \\
\hline & Multas de trânsito & & Alterou & Alterou & Manteve \\
\hline & Negociação Coletiva & & Manteve & Alterou & Manteve \\
\hline & Penalidade & & Manteve & Manteve & Manteve \\
\hline & Participação dos empregados na melhoria de processos e revisão de cláusulas do acordo & Ausente & Manteve & Manteve & Manteve \\
\hline & Participação dos empregados nas discussões do PCCS - Plano de carreiras cargos e salários & Ausente & Manteve & Manteve & Manteve \\
\hline & Prorrogação, revisão, denúncia ou revogação & & Manteve & Manteve & Manteve \\
\hline & Quadro de avisos & & Manteve & Manteve & Manteve \\
\hline & Reabilitação profissional & & Alterou & Manteve & Manteve \\
\hline & Registro de atividades gratificadas & & Excluiu & Ausente & Ausente \\
\hline & Registro de ponto & & Alterou & Manteve & Manteve \\
\hline & Relações de empregados & Ausente & Icluiu & Manteve & Manteve \\
\hline & Repasse das mensalidades do sindicato & & Manteve & Manteve & Manteve \\
\hline & \begin{tabular}{|l|} 
Trabalho em dia de repouso \\
\end{tabular} & & Manteve & Alterou & Manteve \\
\hline & Trabalho nos fins de semana & & Manteve & Alterou & Manteve \\
\hline & \begin{tabular}{|l|} 
Transferência a pedido \\
\end{tabular} & & Excluiu & Ausente & Ausente \\
\hline & Transporte noturno & & Alterou & Manteve & Manteve \\
\hline & Total de Cláusulas & 47 & 62 & \begin{tabular}{|r|}
62 \\
\end{tabular} & \\
\hline
\end{tabular}

Fonte: Quadro elaborado pela autora com base nas consultas aos acordos coletivos de 2002/2003, 2004/2005, 2006/2007 e 2008/2009 da ECT. 


\section{APÊNDICE B}

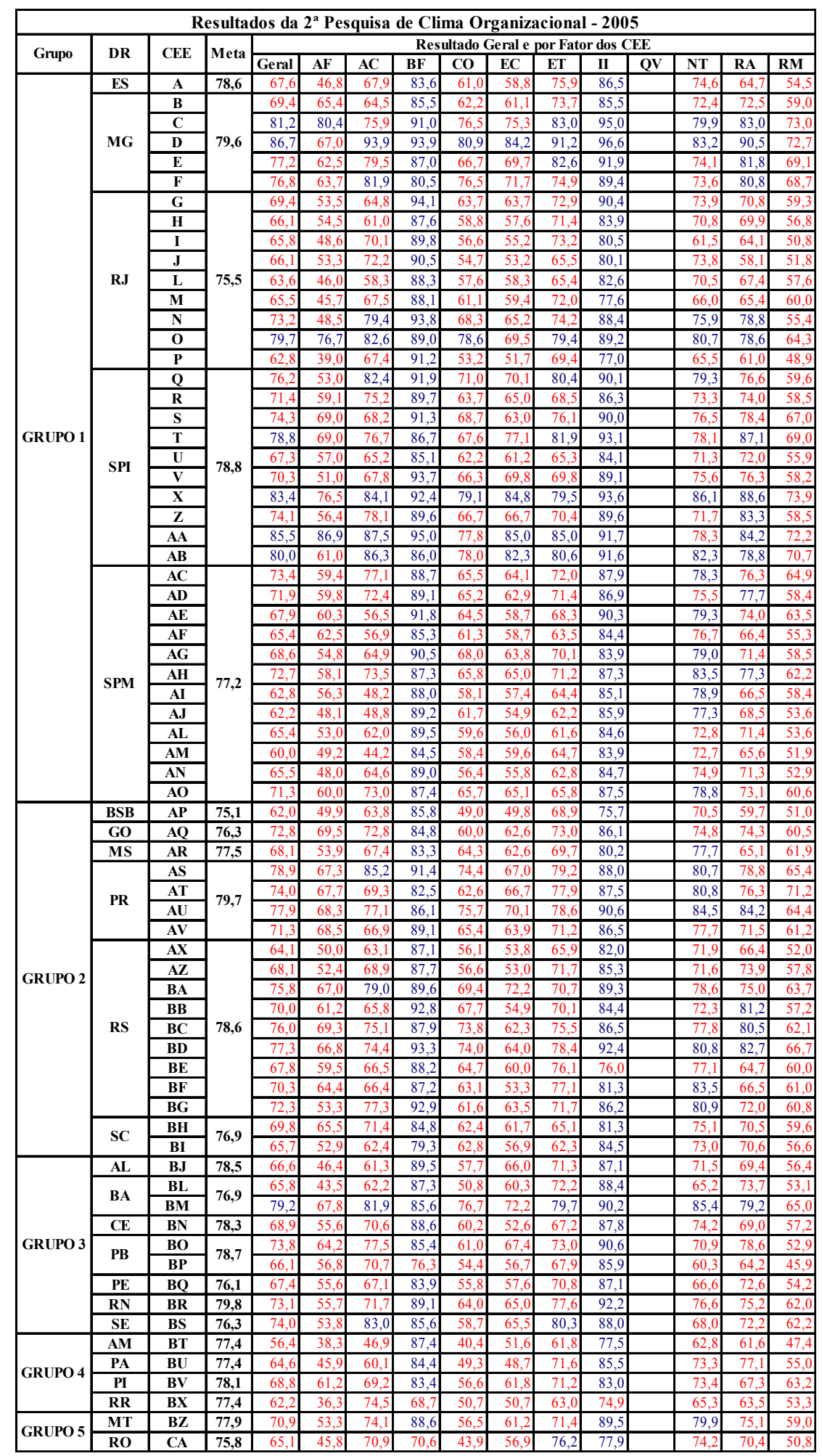

Fonte: Quadro elaborado pela autora com base nos resultados das pesquisas de clima organizacional dos CEE de 2005, 2007 e 2008 da ECT. 


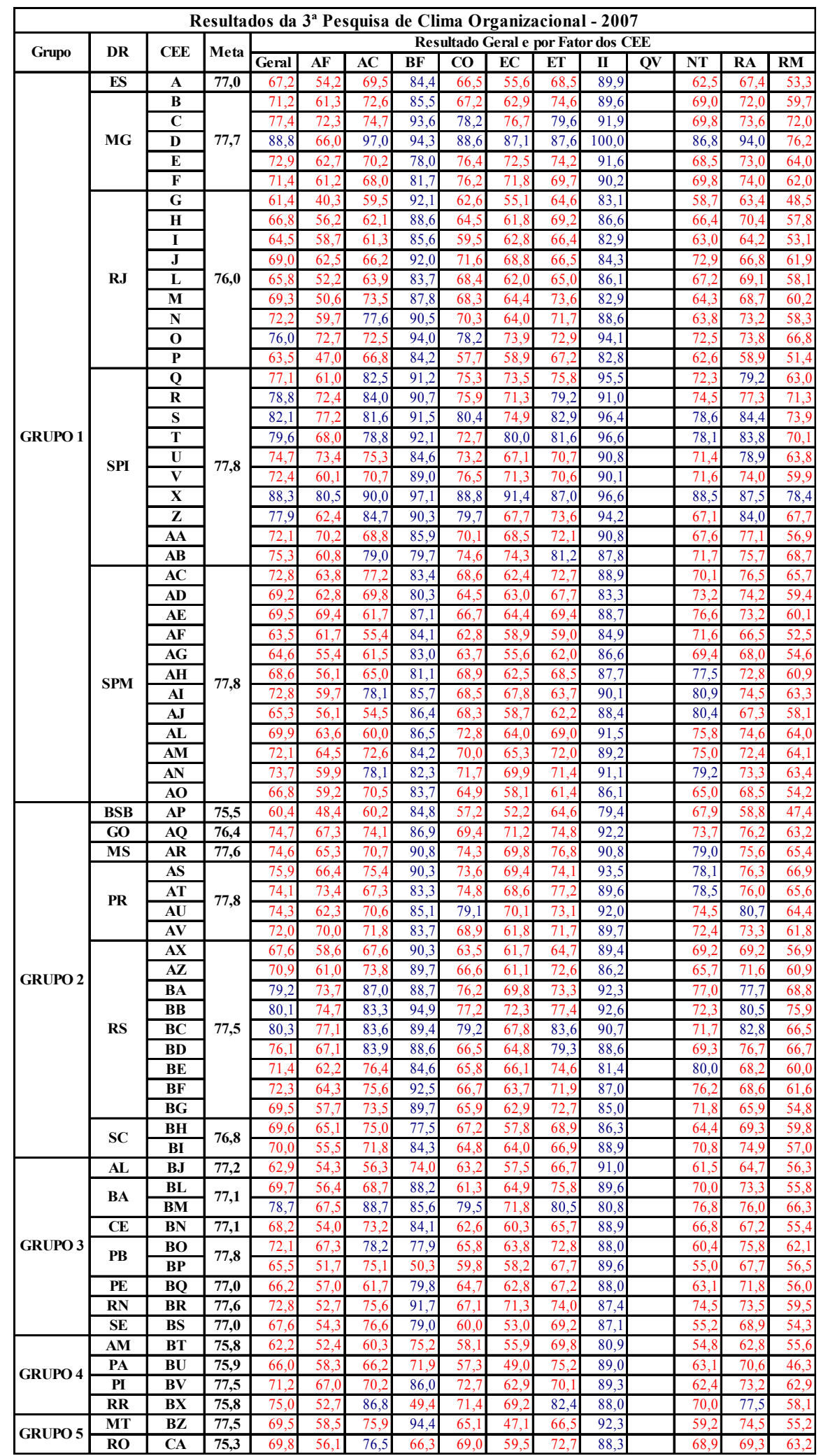

Fonte: Quadro elaborado pela autora com base nos resultados das pesquisas de clima organizacional dos CEE de 2005, 2007 e 2008 da ECT. 


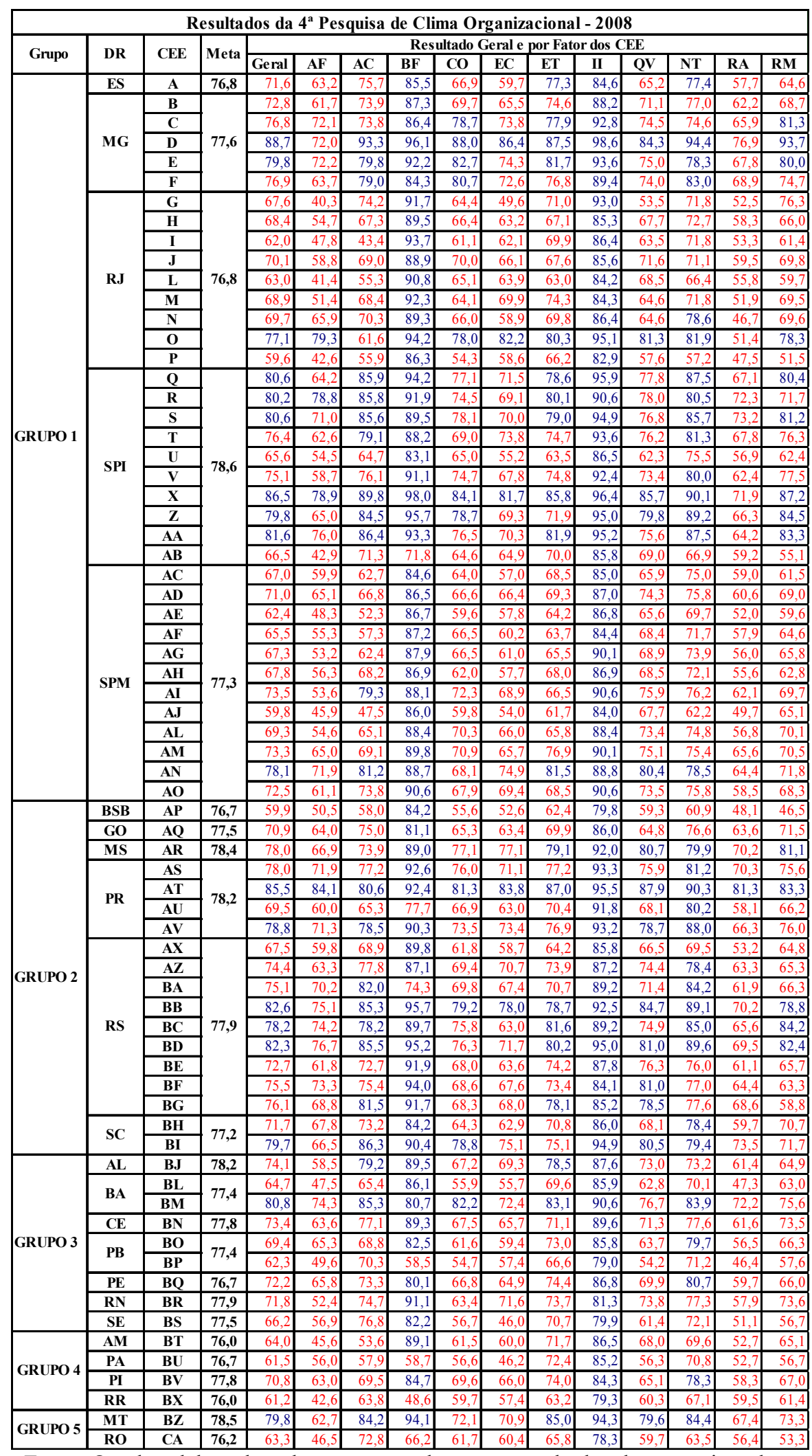

Fonte: Quadro elaborado pela autora com base nos resultados das pesquisas de clima organizacional dos CEE de 2005, 2007 e 2008 da ECT.

Nota: Qualidade de vida (QV), fator incluído na pesquisa de clima de 2008. 


\section{APÊNDICE C}

\begin{tabular}{|c|c|c|c|c|c|c|c|c|c|c|c|c|c|c|c|c|c|}
\hline \multicolumn{18}{|c|}{ Resultado do indicador de desempenho operacional (IDO) do serviço SEDEX } \\
\hline \multirow{3}{*}{ Grupo } & \multirow{3}{*}{ DR } & \multirow{3}{*}{ CEE } & \multirow{3}{*}{ Mês } & \multicolumn{14}{|c|}{ Ano/Meta por DR } \\
\hline & & & & 2005 & \multicolumn{6}{|c|}{2007} & \multicolumn{7}{|c|}{2008} \\
\hline & & & & $99,60 \%$ & $90,00 \%$ & $91,00 \%$ & $92,00 \%$ & $93,00 \%$ & 93,50\% & $94,00 \%$ & $93,00 \%$ & 93,50\% & $94,00 \%$ & $95,00 \%$ & $\overline{96,00 \%}$ & 96,10\% & $\mathbf{9 6 , 3 4 \%}$ \\
\hline & & & JUL & $95,01 \%$ & & & $89,91 \%$ & & & & & & & & $93,07 \%$ & & \\
\hline & FS & $A$ & $\overline{\mathrm{AGO}}$ & $96,27 \%$ & & & $95,53 \%$ & & & & & & & & $92,18 \%$ & & \\
\hline & ES & A & SET & $79,39 \%$ & & & $89,26 \%$ & & & & & & & & $94,47 \%$ & & \\
\hline & & & $\overline{\text { OUT }}$ & $90,35 \%$ & & & $91,19 \%$ & & & & & & & & $94,97 \%$ & & \\
\hline & & & JUL & $97,18 \%$ & & & & & $94,15 \%$ & & & & & & & & $96,61 \%$ \\
\hline & & $\mathrm{B}$ & $\overline{\mathrm{AGO}}$ & $96,04 \%$ & & & & & $96,05 \%$ & & & & & & & & $96,82 \%$ \\
\hline & & B & SET & $90,19 \%$ & & & & & $89,49 \%$ & & & & & & & & $95,14 \%$ \\
\hline & & & OUT & $93,76 \%$ & & & & & $87,23 \%$ & & & & & & & & $96,23 \%$ \\
\hline & & & JUL & $93,90 \%$ & & & & & $91,18 \%$ & & & & & & & & $93,89 \%$ \\
\hline & & $C$ & $\overline{\mathrm{AGO}}$ & $97,91 \%$ & & & & & $94,96 \%$ & & & & & & & & $94,49 \%$ \\
\hline & & C & SET & $88,78 \%$ & & & & & $92,48 \%$ & & & & & & & & $95,09 \%$ \\
\hline & & & OUT & $97,21 \%$ & & & & & $93,59 \%$ & & & & & & & & $95,33 \%$ \\
\hline & & & JUL & $98,37 \%$ & & & & & $91,55 \%$ & & & & & & & & $95,00 \%$ \\
\hline & 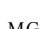 & D & $\overline{\mathrm{AGO}}$ & $96,22 \%$ & & & & & $93,97 \%$ & & & & & & & & $95,07 \%$ \\
\hline & $\mathrm{MG}$ & D & SET & $90,77 \%$ & & & & & $90,78 \%$ & & & & & & & & $94,92 \%$ \\
\hline & & & $\overline{\text { OUT }}$ & $97,19 \%$ & & & & & $92,85 \%$ & & & & & & & & $95,45 \%$ \\
\hline & & & JUL & $94,75 \%$ & & & & & $96,71 \%$ & & & & & & & & $96,25 \%$ \\
\hline & & & $\overline{\mathrm{AGO}}$ & $95,22 \%$ & & & & & $96,93 \%$ & & & & & & & & $96,91 \%$ \\
\hline & & E & SET & $89,54 \%$ & & & & & $96,84 \%$ & & & & & & & & $96,33 \%$ \\
\hline & & & $\overline{\text { OUT }}$ & $98,05 \%$ & & & & & $98,31 \%$ & & & & & & & & $97,15 \%$ \\
\hline & & & JUL & $99,05 \%$ & & & & & $97,19 \%$ & & & & & & & & $95,60 \%$ \\
\hline & & E & $\overline{\mathrm{AGO}}$ & $98,25 \%$ & & & & & $96,87 \%$ & & & & & & & & $94,44 \%$ \\
\hline & & $\mathrm{F}$ & SET & $94,54 \%$ & & & & & $95,32 \%$ & & & & & & & & $94,39 \%$ \\
\hline & & & $\overline{\text { OUT }}$ & $97,07 \%$ & & & & & $97,52 \%$ & & & & & & & & $95,72 \%$ \\
\hline & & & JUL & $97,12 \%$ & & & & & $95,94 \%$ & & & & & & & & $33,66 \%$ \\
\hline & & C. & $\overline{\mathrm{AGO}}$ & $97,53 \%$ & & & & & $97,53 \%$ & & & & & & & & $91,67 \%$ \\
\hline & & G & SET & $76,90 \%$ & & & & & $91,23 \%$ & & & & & & & & $66,67 \%$ \\
\hline & & & OUT & $95,48 \%$ & & & & & $82,88 \%$ & & & & & & & & $82,50 \%$ \\
\hline & & & JUL & $93,27 \%$ & & & & & $91,61 \%$ & & & & & & & & $88,94 \%$ \\
\hline GRUPO 1 & & $H$ & $\mathrm{AGO}$ & $94,58 \%$ & & & & & $97,20 \%$ & & & & & & & & $94,50 \%$ \\
\hline GRUPO 1 & & $\mathrm{H}$ & SET & $60,22 \%$ & & & & & $74,54 \%$ & & & & & & & & $92,15 \%$ \\
\hline & & & OUT & $89,07 \%$ & & & & & $93,90 \%$ & & & & & & & & $92,08 \%$ \\
\hline & & & JUL & $66,67 \%$ & & & & & $88,41 \%$ & & & & & & & & $92,57 \%$ \\
\hline & & 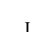 & $\overline{\mathrm{AGO}}$ & $71,43 \%$ & & & & & $93,42 \%$ & & & & & & & & $98,65 \%$ \\
\hline & & 1 & SET & $18,18 \%$ & & & & & $69,19 \%$ & & & & & & & & $98,28 \%$ \\
\hline & & & OUT & $40,00 \%$ & & & & & $94,44 \%$ & & & & & & & & $98,50 \%$ \\
\hline & & & JUL & $93,31 \%$ & & & & & $97,44 \%$ & & & & & & & & $86,21 \%$ \\
\hline & & I & $\overline{\mathrm{AGO}}$ & $95,04 \%$ & & & & & $98,48 \%$ & & & & & & & & $94,34 \%$ \\
\hline & & $\mathrm{J}$ & SET & $76,68 \%$ & & & & & $65,46 \%$ & & & & & & & & $94,30 \%$ \\
\hline & & & OUT & $87,74 \%$ & & & & & $69,43 \%$ & & & & & & & & $89,82 \%$ \\
\hline & & & JUL & $93,08 \%$ & & & & & $94,52 \%$ & & & & & & & & $93,95 \%$ \\
\hline & & & $\overline{\mathrm{AGO}}$ & $95,59 \%$ & & & & & $96,76 \%$ & & & & & & & & $93,35 \%$ \\
\hline & RJ & $\mathrm{L}$ & SET & $70,77 \%$ & & & & & $72,23 \%$ & & & & & & & & $86,56 \%$ \\
\hline & & & $\overline{\text { OUT }}$ & $84,99 \%$ & & & & & $90,01 \%$ & & & & & & & & $93,23 \%$ \\
\hline & & & JUL & $99,02 \%$ & & & & & $97,54 \%$ & & & & & & & & $53,56 \%$ \\
\hline & & & $\overline{\mathrm{AGO}}$ & $98,89 \%$ & & & & & $97,56 \%$ & & & & & & & & $97,14 \%$ \\
\hline & & $\mathrm{M}$ & SET & $81,14 \%$ & & & & & $79,13 \%$ & & & & & & & & $95,33 \%$ \\
\hline & & & OUT & $94,98 \%$ & & & & & $89,14 \%$ & & & & & & & & $96,49 \%$ \\
\hline & & & JUL & $94,15 \%$ & & & & & $97,71 \%$ & & & & & & & & $96,31 \%$ \\
\hline & & V & $\overline{\mathrm{AGO}}$ & $95,11 \%$ & & & & & $98,14 \%$ & & & & & & & & $95,33 \%$ \\
\hline & & $\mathrm{N}$ & SET & $71,27 \%$ & & & & & $80,46 \%$ & & & & & & & & $93,97 \%$ \\
\hline & & & OUT & $94,85 \%$ & & & & & $96,64 \%$ & & & & & & & & $94,95 \%$ \\
\hline & & & JUL & $85,22 \%$ & & & & & $95,99 \%$ & & & & & & & & $96,25 \%$ \\
\hline & & & $\mathrm{AGO}$ & $91,99 \%$ & & & & & $96,24 \%$ & & & & & & & & $95,41 \%$ \\
\hline & & 0 & SET & $73,79 \%$ & & & & & $71,35 \%$ & & & & & & & & $95,92 \%$ \\
\hline & & & OUT & $87,03 \%$ & & & & & $96,21 \%$ & & & & & & & & $96,44 \%$ \\
\hline & & & JUL & $94,02 \%$ & & & & & $93,29 \%$ & & & & & & & & $66,41 \%$ \\
\hline & & $P$ & $\overline{\mathrm{AGO}}$ & $93,74 \%$ & & & & & $96,73 \%$ & & & & & & & & $93,83 \%$ \\
\hline & & $r$ & SET & $87,61 \%$ & & & & & $75,50 \%$ & & & & & & & & $95,32 \%$ \\
\hline & & & OUT & $89,04 \%$ & & & & & $81,60 \%$ & & & & & & & & $95,05 \%$ \\
\hline
\end{tabular}

Fonte: Quadro elaborado pela autora com base nos resultados dos indicadores de desempenho operacional (IDO) do serviço SEDEX dos CEE de 2005, 2007 e 2008 da ECT. 


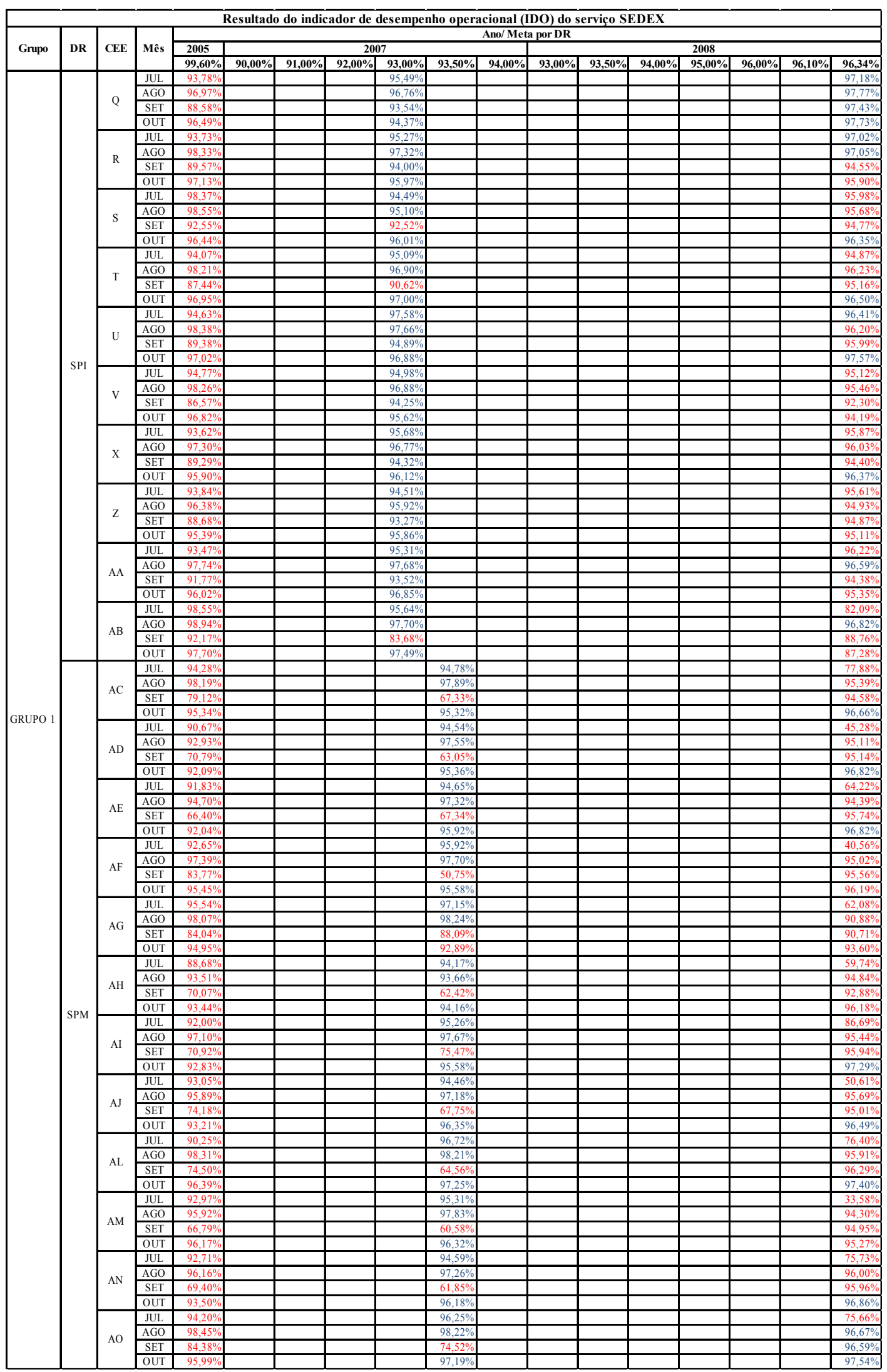

Fonte: Quadro elaborado pela autora com base nos resultados dos indicadores de desempenho operacional (IDO) do serviço SEDEX dos CEE de 2005, 2007 e 2008 da ECT. 


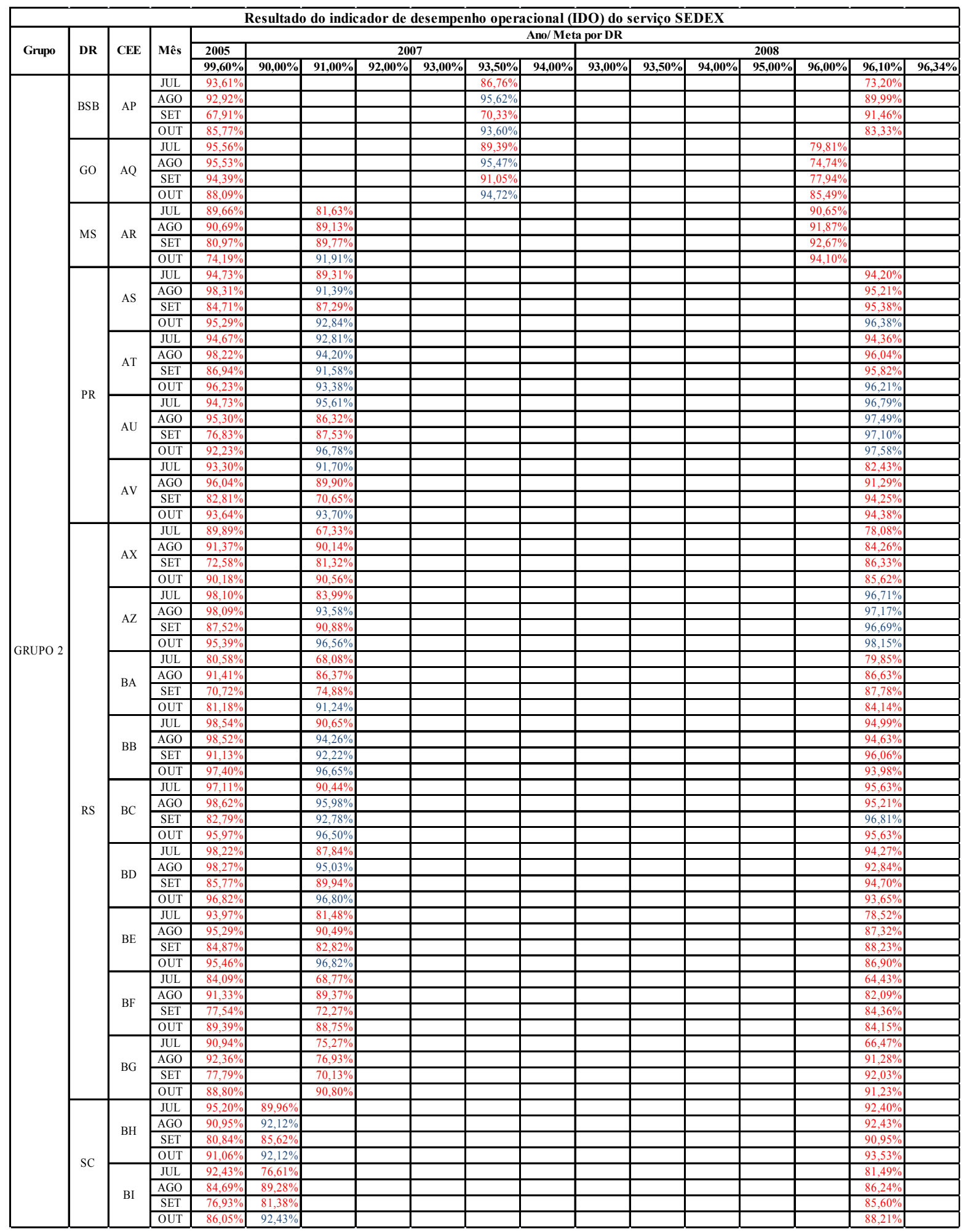

Fonte: Quadro elaborado pela autora com base nos resultados dos indicadores de desempenho operacional (IDO) do serviço SEDEX dos CEE de 2005, 2007 e 2008 da ECT. 


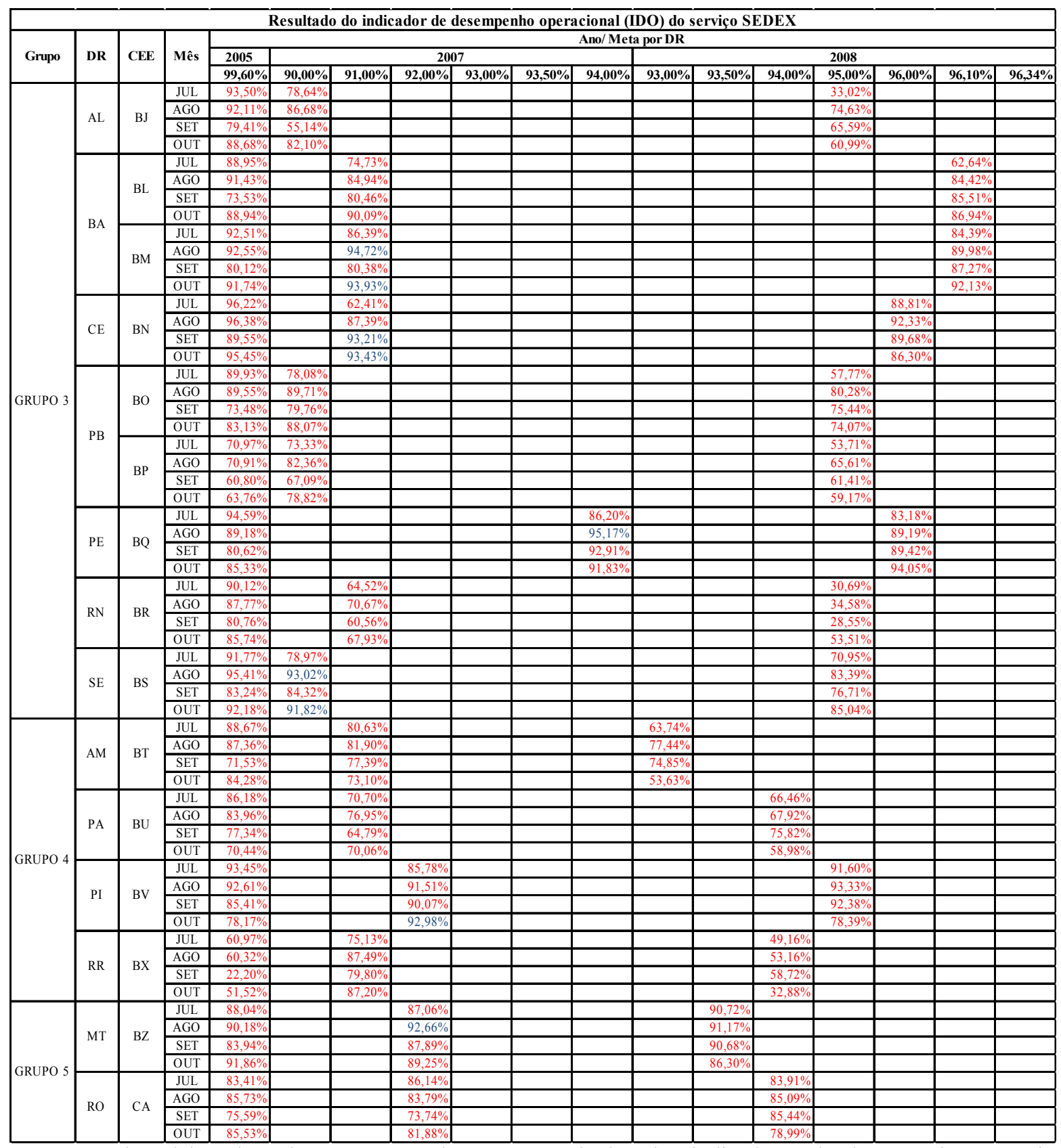

Fonte: Quadro elaborado pela autora com base nos resultados dos indicadores de desempenho operacional (IDO) do serviço SEDEX dos CEE de 2005, 2007 e 2008 da ECT. 